\title{
A value-theoretic approach to economic dynamics and evolution-synthesizing different Marxian modules in a simulation model
}

\section{Part I: foundations}

\author{
Frank Beckenbach ${ }^{1}$
}

Published online: 6 May 2020

(C) The Author(s) 2020

\begin{abstract}
The background for the present elaboration is twofold: firstly, the ongoing debate about whether the Marxian theory of value has been damaged (or even destroyed) by the alleged impossibility of solving the 'transformation problem' and secondly, the fact that almost all of the (later) economic manuscripts of Marx are now accessible due to the new publishing activities in the MEGA project. In regard to the former, it can be concluded that the rationale of the Marxian value concept is distorted by its Ricardian elements (including the labour theory of value). In regard to the latter, the later economic manuscripts as well as the few economic monographs published during Marx's lifetime indicate that Marx was figuring out different modules for his value theory which are not really related to each other, let alone thoroughly synthesized with one another. Hence, in this elaboration, an attempt is made to reformulate this contested and fragmented value-theoretic torso by focussing on the non-Ricardian essentials of the value theory. This (de-)construction is then used as a basis for linking the different value-theoretic modules in terms of their ability to explain economic evolution. With this perspective, the dynamic nature of these modules is emphasized. Hence, in addition to a conceptual discussion of the value-theoretic modules, a simulation model is suggested for their integration. In this way, it can be shown that the value theory can be substantiated in a consistent stepwise fashion, and the conditions for generating the long-term results expected by Marx can be specified.
\end{abstract}

Keywords Marx · Theory of value - Evolution - Social exploitation · Class antagonism • Accumulation $\cdot$ Reproduction $\cdot$ Profit rate $\cdot$ Crisis $\cdot$ Simulation;

JEL classification $\mathrm{B} 14 \cdot \mathrm{B} 15 \cdot \mathrm{B} 51 \cdot \mathrm{B} 52 \cdot \mathrm{C} 63 \cdot \mathrm{E} 11 \cdot \mathrm{P} 10$

Frank Beckenbach

beckenbach@wirtschaft.uni-kassel.de

1 University of Kassel, Kassel, Germany 


\section{Introduction}

The modern discourse in economics is (more than ever) about figuring out and applying model constructions. The purpose of these constructions is mainly to give orientation for discussions within the science of economics, and their role for empirical research is only of secondary importance (if it exists at all). Selecting mathematical methods and attributing economic semantics to the model elements are the essential features of these constructions. This discourse - and the specific way to use specific mathematical models - is part of the scientific procedures by which a mainstream economics is established and fostered. These procedures include defining standards of professionality, establishing criteria for selecting articles to be published in scientific journals and building scientific reputation based on citation frequency (cf. Fourcade 2009; Beckenbach 2019).

This construction-based discourse of mainstream economics has spillover effects for the heterodox (non-mainstream) traditions of economics. Broadly considered, two such effects can be specified: firstly, a clarification effect that occurs through the application of mainstream tools as a source of new insights and, related to that, as a means of obtaining an updated assessment of the strength and weakness of the concepts or theories at stake; secondly, a castration effect that occurs through the elimination of elements not appropriate for such a model imposition - which are in most cases precisely those elements that are critical of the mainstream foundation.

Not surprisingly, this kind of spillover can be observed also for the Marxist tradition in economics. It consists of reinterpreting Marx's economic writings from the perspective of modern general equilibrium analysis by referring to the following model components: (i) the simultaneous production of goods by goods, (ii) fixed technologies and input/output coefficients, (iii) constant returns to scale, (iv) convex production sets or cones, (v) equilibrium in terms of quantities and income distribution, (vi) multiple alternatives/dual optimization under constraints and finally (vii) balanced growth. In each of these components, a specific combination of mathematical tools (such as equations and inequalities, linear (matrix-)algebra, eigenvalues, saddle points/fix points and convex sets) and economic semantics (technology, commodities, price, profit, interest and the like) has been determined in an almost undisputed fashion. Originating mainly in the works of von Neumann (1945/6), Debreu (1959) and Leontief (1941) and (partly) synthesized by Sraffa (1960), ${ }^{1}$ these elements have been (in different combinations) applied in reinterpreting Marx's economic writings (e.g. by Steedman (1977), Morishima (1973) and Roemer $(1981,1982)$ ).

This is not the place to summarise and assess all these applications and their repercussions, but it seems obvious that the clarification effect (as mentioned above) generated by these applications has made the status of the labour theory of value increasingly ambiguous. If considered as a theory about labour 'embodied' in commodities, it seems to run into difficulties of (at least partial) self-contradiction and should be abandoned or reformulated as a theoretical construct. But - according to the process sketched above - this is accompanied by a dubious castration effect consisting in suggestions to abandon value theory as such and to substitute it by selectively combining the above model components (i)-(vii). This is tantamount to getting rid of the main features of value theory, i.e. explaining precarious social

\footnotetext{
${ }^{1}$ cf. Arrow/Hahn (1971, pp. 10, 74) for the link between von Neumann and Debreu, Kurz/Salvadori (2001) for the link between von Neumann and Sraffa, Parys (2016) for the link between Leontief and Sraffa and Lopes/Neder (2017) for their affinity to (socialist) planning perspectives.
} 
interaction, money, social exploitation, accumulation, out-of-equilibrium reproduction and contested allocation as historically specific forms of capitalism. The following elaboration tries to escape from this trap. This necessitates going back to the Marxian conceptualization of these topics and assessing the role of the reference to (labour) values in this analysis.

An advantageous background for conducting such an assessment has been provided by the publication of Marx's 'late' economic manuscripts, which has now been completed (cf. MEGA II). This undercuts the reading of Engels' publication of Marx's manuscripts as 'volume II' and 'volume III' of 'Das Kapital' as being a more or less consistent whole. ${ }^{2}$ Rather, it is now clear that the Engels' edition is a very selective compilation from different stages of Marx's research process. ${ }^{3}$ Taking this into account, however, does not properly lead to the conclusion that Marx's late economic writings are simply an unstructured intellectual quarry or a mere assembly of self-doubts that can be employed by the opponents of Marx's approach as an easy opportunity for self-assured confirmation for their own projections (cf. e.g. Kurz 2018) - the origin of which was exactly the inappropriate reading suggested by the Engels' edition. Rather, this new situation begs the question how Marx's broad concept (firstly resumed in the 'Grundrisse', cf. MEGA II/ 1.1-1.2) has been differentiated into various parts and how these parts are linked together to form a whole in the later manuscripts. ${ }^{4}$ According to this question, three propositions come to mind when looking at the totality of Marx's late economic manuscripts:

(a) Marx's research process manifests an increasing tension between two basic concepts for linking the various parts: on the one hand, the (Ricardian) idea of labour as an overarching denominator of all social activities and on the other hand, the (Hegelian) unfolding of social forms. In other words, in Marx's later studies, it becomes increasingly difficult to subsume social forms under the dictum of embodied labour. ${ }^{5}$

(b) The circular nature of Marx's research process is the reason why most parts of the manuscript devoted to the capitalist process as a whole have been written earlier than the published volume I of 'Das Kapital' ${ }^{6}$ and also earlier than most of the

\footnotetext{
${ }^{2}$ Furthermore, it shows that even for 'volume I' of 'Das Kapital', no comprehensive edition exists. For a detailed analysis of the Marxian research chronology, cf. Heinrich (2011, pp. 161).

${ }^{3}$ Hence, from a methodological point of view, it seems to be totally inappropriate to link or confront the notions of value in volume I and those suggested in the earlier manuscript on the capitalist process as a whole as Engels did in his proclaimed contest (cf. MEGA II/13). In combination with the superimposition of an equilibrium framework, this stylizing of an explanation problem on shaky grounds was the background for a 'rational destruction' of Marx's research agenda which took place later on under the headline of a 'transformation problem' (cf. Howard/King 1989, pp. 21, pp. 42)

${ }^{4}$ There are either only rough ideas suggested by Marx about how to link these specifications (e.g. how to integrate the vol. I expertise on surplus production into the part about the tendential fall of the profit rate) or no hints at all on how to do that (e.g. how to synthesize the views on accumulation in vol. I and the reproduction analysis elaborated later on; cf. Harvey 2013, pp. 313, pp. 371; Desai 2004, pp. 67).

5 This is quite significant in his studies of the contemporary credit system and agricultural system (cf. MEGA II/4.2, pp. 469, pp. 667).

${ }^{6}$ In these older manuscripts, Marx seems to have been more strongly influenced by the work's classical predecessors than in his published vol. I of 'Das Kapital'. One indicator for this is his uncritical adoption of the classical notion of competition in the older manuscript (e.g. by simply assuming equal rates of surplus value as well as of profits in all industrial branches; cf. MEGA II/4.2, pp. 212, pp. 230) which is not compatible with the dynamics of surplus value generation being the main topic of vol. I. Another indicator is the emphasis he puts on characterizing the social conditions of value and value form development - both radically criticizing the classical approach - in the different editions of vol. I.
} 
manuscripts dedicated to the circulation process of capital. Especially as regards the specified requirements for the reproduction and circulation of capital as a whole, it seems reasonable to postulate a need to update the older manuscript about the capitalist process as a whole ('Gesamtprozess des Kapitals') by incorporating these new insights about the circulation process.

(c) Looking at the concept as a whole, it seems obvious that Marx's method of presentation ('Darstellungsweise') includes a recursive notion of value: its substance as well as its form is specified successively. Hence, there is no reason for an abstract and unchanged understanding of what value means. Accordingly, this kind of presentation has a multi-level property in that the same economic contexts are analysed at different levels of abstraction (e.g. simple and capitalist mode of circulation) ('Zirkellauf der Darstellung').

Based on these propositions derived from the MEGA edition, an attempt is made in the following elaboration to specify the value concept without referring to the Ricardian notion of labour (embodied) as a more or less constant substance of value (Section 2) and to interpret the various modules of Marx's analysis as a recursive unfolding of a value-theoretic treatment of the core features of capitalism (Section 3). Finally, these modules are synthesized in a conceptual model (Section 4). Part II of the article will present simulation experiments with the suggested model and draw some conclusions.

\section{2 (De-)constructing value theory}

\subsection{Limits and aporia of Marx's value theory}

Basic ideas about the foundation of value theory have been put forward by Marx in the first section of the first volume of 'Das Kapital' (cf. MEGA II/6, pp. 69) published during his lifetime. Surprisingly, Marx starts his elaboration with the statement that capitalism is tantamount to a generalized commodity production or to a closed system based on production by means of commodities. Hence, for him, it is of utmost importance to analyse these commodities. Taking the exchange of commodities as a starting point, two different aspects of value are identified: its 'substance' as a common denominator of the exchanged commodities and its 'form' as a historically specific expression of the social character of isolated but interdependent activities of economic agents. By dissolving both aspect of value into labour and by classifying all exchanged entities as commodities, they are all considered manifestations of labour. Hence, the labour theory of value is the background for the commodity-related closed system vision that Marx has about the capitalist mode of production. This implies that its observable specificities such as money and wage labour are subsumed under this vision and also are dealt with as commodities (though having some peculiarities) (cf. MEGA II/6, 118, pp. 183).

This foundation of value theory has several flaws: Firstly, it is neither historically nor conceptually appropriate to start with an 'exchange of commodities'. The latter is possible only if all commodities to be exchanged are related to a common entity, 
money, which insofar cannot be simply a (private) commodity. ${ }^{7}$ Secondly, there is no need for a common denominator ('substance of value') to exist for such an exchange between a private commodity and the common reference entity because they are essentially different. ${ }^{8}$ Thirdly, the quantitative relationship between the two depends on a specification of the 'form of value', i.e. of the social validation a private activity can acquire for its product. Fourthly, it is not necessary to dissolve the regulation factors for such a social validation into one dimension and if so, this need not be the labour content (whatever this may be and however it is measured).

Hence, contrary to the conclusion drawn from applying mainstream constructions for depicting Marxian concepts, it is not the value theory itself that becomes redundant by taking the labour theory seriously but rather the other way around: by taking the explanatory task of value theory seriously, it is the narrowing to a labour theory of value that is rendered ambiguous. The foundation of value theory by a labour theory is an unnecessary and implausible limitation, and the form of value has to be delinked from such a foundation. Instead, the focus of the value concept is on the conditions and on the outcome of a precarious interaction process between isolated economic agents on different levels of theoretical abstraction. Furthermore, contrary to the Marxian vision of capitalism as generalized commodity production, it can be concluded from these social conditions underlying the articulation of values that not all requirements for the capitalist mode of production can be (re-)produced by means of commodities but that it rather necessitates processes from outside the commodity world. This is the case not only with (not privately owned) natural conditions but also with money and labour (cf. Polanyi 2001). Both are 'commodified' but not simple commodities as Marx makes them out to be, because they raise (unsolvable) conflicts between private and social interests. In that sense, the scope of value theory including these elements is more limited and more enhanced at the same time. ${ }^{9}$

Given this relaxation of value theory and in particular the abandonment of the idea of a more or less fixed substance of value, it is possible to bring the different modules that Marx elaborated for his concept into a closer relation with one another. From this perspective, these modular specifications are a stepwise concretion of the form of value in capitalist production, each of which contains a modification of the determining factors for the form and amount of value.

\subsection{A modified value theory}

In qualitative terms (related to the value form), the value theory circumscribes the result of a precarious interaction process which is based on two social conditions (sc): (sc 1) interdependence of individual activities and (sc 2) the private nature (i.e. separation) of these activities (cf. MEGA II/6, pp. 102). This implies that the (conflicting) value forms and their moderation by a generalized medium of commensurability are an outcome of interacting heterogeneous agents. Hence,

\footnotetext{
${ }_{7}^{7}$ Cf. the reasoning of Marx himself (cf. MEGA II/6, pp. 82). Taking the commodity owners as rivals would imply that everyone would strive to have their own private product accepted as a reference for all other commodities.

${ }^{8}$ The relation of a singular commodity to money is a polarity relation and not in itself an equivalence relation, i.e. it is not symmetrical and transitive.

${ }^{9}$ In the present elaboration, this will be demonstrated only for wage labour.
} 
the specificity of value is that the social nature of private activities is only expressed (therefore, only visible) as a property of the agent's product, and through this, it is transformed into a commodity. This 'reification' ('Verdinglichung') increases if more commodities are used to produce commodities and to generate more complicated commodity-based relationships (e.g. like capital and finance). In that sense, value depicts that the social relations are becoming thingified restrictions which are independent from single individual activities and determine an obligation to follow or, even worse, individual activities are becoming subordinated to these commodity relations. Therefore, value is a specific kind of overarching ordering structure ${ }^{10}$ for individual activities giving the product of these activities their temporary 'social weight' resulting from social requirements and the limited way to meet these requirements. It should be evident from this that value theory does not entail an equilibrium concept that presupposes an ex ante compatibility of individual activities and their products. Rather, this compatibility is generated by a process of conflict-ridden interaction ${ }^{11}$ and is manifest only as a hidden 'law': it is not visible and nor is it controllable for individual agents. According to that, value theory is about developing the different components (or modules) of the ordering structure for individual activities and shows how these components adapt to each other. Hence, value theory is focussing on an aggregated level of activities and therefore is mainly related to the macro-level as well as to the meso-level considered from a medium and long-term perspective. This is accomplished by the ideal-typical analysis of the firm at the micro-level.

In quantitative terms (related to the amount of value), value is expressed in a medium which is 'generated by society" ${ }^{12}$ for the sake of depicting commensurability under the social conditions mentioned above. This medium is called money. Hence, value is quantitatively expressed in terms of money (value price). This value price is different not only from the oscillating 'market price' (being its background) but also from the 'natural price' of classical political economy (cf. Smith 1979/1784, pp. 47, pp. 72; Ricardo 1975, pp. 88, 196) as well as from the 'normal price' of Marshallian neoclassical economics (cf. Marshall 1972/1920, pp. 281, pp. 302). It circumscribes a level and structure of market prices (in intra-temporal as well as intertemporal terms), enabling the reproduction of the commodity-based society as a whole. In that sense, the value price is tantamount to an adaptively generated (and distorted) social compatibility price.

This value price (or social compatibility price) is fundamentally shaped by an additional assumption about the social background of economic activities: (sc 3 ) the existence of one social group ('class') having access to means of production, price-

\footnotetext{
${ }^{10}$ Such an ordering structure on the meso-level as well as the macro-level is generated by a multitude of different activities at the micro-level and is influencing the latter in the medium and long term.

${ }^{11}$ On the level of individual agents, this conflict can be conceptualized as a (positive or negative) divergence between amounts of money delivered to others (via selling) and amounts of money received from others (via buying), triggering crisis-like adaptation procedures (cf. Benetti/Cartelier 1980, pp. 42 for such an approach). In that sense, values are derived from individual explorations in terms of selling and buying.

${ }^{12}$ From a conceptual as well as from a historical perspective, this generation of money is neither a result of a political planning procedure nor a self-organized outcome of interacting economic agents. Rather, it is a mixture of both in that unsolvable conflicts generated by the latter suggest the need of an (evolving) institutional embeddedness (cf. Aglietta/Orléan 1982, pp. 25; 2002, pp. 98).
} 
setting capabilities and money (i.e. capitalists) and one group without such access (i.e. wage labourers) being urged to work for the capitalists in order to get money. Hence, for Marx, this value price is the basis for the aggregated analysis of the ordering structures in a capitalist mode of production and circulation. Accordingly, the constituents of value price are characterized by features totally absent in classical and neoclassical approaches:

- The value price is a social weighting of individual activities in that for each type of activity, a ruling quantification standard is established.

- Depending on the varying role of the elements of production, and to a certain degree on the calculation device of capitalist owners for means of production, the value price is composed of 'constant capital', 'variable capital' and 'surplus value'.

- The value price is a means to clarify the difference between the costs of production on the one hand and the surplus on the other hand, documenting the degree of success in organizing the combination of means of production and labour. The surplus itself is the background for planning and executing the increase of capital applied in production, i.e. for accumulation.

- Via accumulation, the value price determines the requirements in terms of available means of production especially of available wage labourers, who cannot be produced in a capitalist fashion.

- Even if these requirements are met, the question arises if the combined reproduction of old and newly accumulated capital is possible at the social level of capital as a whole, or if an adaptation of the value price is necessary for that.

- Finally, the value price, being established on the sectoral level, is exposed to competitive tensions that generate value reallocations between the sectors.

These value-determining components are developed by Marx in a stepwise fashion (according to his methodology). On each of the different levels of value analysis, the law-like nature of value is depicted in terms of (conditional and timedependent) equivalence relations ${ }^{13}$ of different amounts and components of value. This means that, according to the aggregated perspective explained above, at each of these levels of analysis, a social synthesis of individual value aspirations (polarity relations in terms of value forms) is assumed to occur. Between these levels, adaptations take place so that the values on the different levels (simple value, reproduction value and competition value) differ in quantitative terms, but they are generated out of each other in such a way that what counts as value becomes more and more complicated. ${ }^{14}$

\footnotetext{
13 That means for every time-dependent aggregated value term, the conditions of reflexivity, symmetry and transitivity hold. But there is no need that these properties are also features of the disaggregated terms: multiple prices for the same commodity and unexhausted arbitrage opportunities on the level of individual prices are, for example, possible. Hence, money is a necessary but not sufficient medium for realizing equivalent relations (cf. Mirowski 1991, p 715 and Krause 1979, pp. 46 who is not taking this into account).

${ }^{14}$ This unfolding of the adaptation requirements of economic aggregates is different from the usual equilibrium analysis in economics: it is neither about compatibility of individual plans nor about equalizing demand and supply. Furthermore, this signifies that there is a fundamental difference to applying any kind of 'conservation principle' borrowed from physics (cf. Mirowski 1991 for a similar attempt dubbed 'postmodernist').
} 
It is obvious that the (basic) value analysis derived from precarious interaction-pertaining to cost-related social weighting, exploitation of wage labour, accumulation, reproduction and allocation-necessitates the existence of money, at least in an elementary form ${ }^{15}$ as needed for fulfilling essential functions. ${ }^{16}$ Firstly, there is a need for a stable generally accepted unit of account. ${ }^{17}$ Secondly, it is necessary to have a possibility to pile up cash either for pursuing market transactions diverging in terms of time and/or for achieving a minimum amount for an accumulation project. Thirdly, it is necessary that an initial amount of money is available in such a way that commodity circulation required for realizing the ordering structures is possible (cf. Krause 1979, Beckenbach 1987, pp. 177). ${ }^{18}$ At this level of basic value analysis, it is simply assumed that this elementary form of money partly exists a priori, partly can be acquired by giving away commodities (mimicking the minting process) and that it fulfils the functions mentioned above. This is not to deny that money interferes in the interaction processes being the main focus of basic value analysis. Quite the contrary, but deciphering these influences necessitates taking into account that money cannot be linked to commodity exchange simply via commodity money. Rather, the development of money cannot be separated from institutions and their regulating influence. Hence, to take these influences into account requires a broader perspective (enhanced value analysis), for which the basic value analysis is a starting point. $^{19}$

Advancing values for creating additional values ('Verwertung des Werts') is the driver for the circular flow ('Kreislauf') of capital through the forms of money, commodity input, production, commodity output and money again. Furthermore, the pressure of being socially successful in terms of value requires the accumulation of capital (by investing at least a part of the additional values). Hence, value theory is not only dynamic in portraying the sequence of the precarious interaction conditions implied in capital's circular flow but it also illuminates the possibilities and the limits to growth of social valuation. Based on that, access to evolutionary aspects can be provided by such a value theory at three levels: firstly, on the mesolevel by analysing the way in which different features of the precarious economic interaction process unfold over time. This unfolding implies external and internal contingencies: the former are the available population and the way institutional regulation takes place; the latter are the conditions for increasing the surplus value (i.e. the combination of the different methods appropriate for that) and the power of wage labour. Hence, a value-theoretic explanation of economic evolution is

\footnotetext{
${ }^{15}$ Conceptually, the necessity of money can be derived from Marx's development of value forms if his labour theory of value is stripped off (cf. Benetti/Cartelier 1980, pp. 141 for such an attempt).

${ }^{16}$ Hence, value is not constituted by money (e.g. Mirowski 1991, 713; Orléan 2014, 4 argue). Rather, value circumscribes a social context which is made viable by money.

${ }^{17}$ Taking into consideration that this unit of account is not related to any useful commodity, the acceptance of the former can only be derived from an institutional legitimacy in combination with its effect of reducing transaction costs. Contrary to the more elaborated analysis, in the basic value analysis, it is assumed that the creation, circulation and substitution of the unit of account have no influence on the value price.

${ }_{19}$ According to the class-theoretic assumptions, wage labourers do not possess an initial money endowment.

${ }^{19}$ At this enhanced level of analysis, more concrete observable phenomena like pathological 'liquidity preference' (Keynes 1974/1936), lack of trust in currency (Orléan 2014, pp. 136) and speculation (Orléan 2014, pp. 226) can be explained systematically.
} 
tantamount to combining the essential features of value dynamics with their contingencies in terms of path variations. ${ }^{20}$ Secondly, on the macro-level by linking the ways in which different contingencies come into play and through this create different 'regimes' for the operation of the value system as a whole. These regimes create different paths of capitalist development located between abstract modelling on the one hand and real history on the other hand. ${ }^{21}$ Thirdly, on the micro-level, singular evolutionary processes can be distinguished. By disaggregating the value terms, the evolution of socially shaped singular technologies (in production and consumption) or the evolution of specific institutional settings (e.g. in terms of money policy or social policy) can be brought into focus. In that sense, the basic value analysis of this elaboration can be seen as a starting point for an enhanced evolutionary approach on different levels, the interdependence of which gives a comprehensive understanding of the economic evolution as a whole. ${ }^{22}$

Such a reconceptualization of a dynamic and-at least potentially evolutionary-value theory is distinct from its modern 'labourist', 'physicalist' and 'monetarist' interpretations. ${ }^{23}$ In the labourist interpretation (e.g. by Shaikh 1981; Moseley 2016), it is maintained that the source of value is labour and that the exchange of commodities is regulated by 'embodied labour'. Based on that, it is seen as possible either to transform value aggregates into price aggregates or at least to dissolve aggregates in price terms into aggregates in labour value terms. Consequently, wage labour and money are mainly dealt with in commodity terms and their non-commodity elements are treated as exogenous elements (like 'class struggle' or 'quantity of money'). In the physicalist interpretation (e.g. by Steedman 1977), it is supposed that value can be deciphered as a complete set of sectoral technologies in terms of input as well as output quantities of products and labour on the one hand and proportions of these quantities ('relative prices') determined by allocation requirements like an equal 'profit rate' in all branches on the other hand. In such a perspective, value theory becomes redundant and is substituted by externally determined 'physical' entities (technology and real wages). But this can only be maintained for a crude (labour-embodied) version of value theory. If the latter is specified along the value form perspective with its

\footnotetext{
${ }^{20}$ Taking the usual criteria of evolutionary economics, the question arises if such an approach can be classified as 'evolutionary' at all (cf. Hodgson 1997, pp. 14). Novelty creation is dealt with only implicitly in that the dynamics of surplus value are intimately linked to that; reductionism may be implied because the whole reasoning is in value terms; gradualism runs contrary to the Marxian vision of the revolutionary change of the mode of production, and finally, the metaphorical link to biology is totally absent. Against this background, the Marxian contribution is an attempt to broaden the evolutionary perspective by embedding a single technological and institutional analysis into 'modes' or 'regime' of production and thereby overcoming its explicit or implicit biological foundation.

${ }^{21}$ A prominent example is the identification of 'Fordism' and 'Post-Fordism' (cf. Aglietta 2015, pp. 407).

22 This dynamic and evolutionary reading of value theory is essentially different from its reduction to a static supplement of equilibrium analysis (cf. Laibman 2012, pp. 13, pp. 20, pp. 37, pp. 44, pp. 52).

${ }^{23}$ This is only a rough classification in order to characterize the approach suggested in this elaboration. A more subtle overview of modern classical/Marxist approaches should take into account that the labourist camp can be divided in qualitative and quantitative approaches; in the physicalist camp, primalist (only material related) and dualist (material and value related) approaches can be distinguished. The same is true for the monetarist camp in that either only money relations or money and physical relations (derived from the money relations) are taken into account; cf. De Vroey $(1982,1985)$ for an early attempt that remains to be continued.
} 
focus on precarious interaction, no such clear-cut proportions between sectors exist because neither the product relations nor the suggested allocation device is given a priori in such a context. Rather, values are a dynamic vehicle for figuring out the ruling product relations in terms of technologies and for relating the different reproduction and allocation requirements over time. In the monetarist interpretation $^{24}$ (e.g. by Cartelier 2018; Orléan 2014), any a priori portrait of technical interdependencies (in terms of product-related input/output relations) is abandoned due to the informational limits inherent in market interaction. Taking the level of individual agents, the precarious nature of such agents can only be specified by conflict-laden consolidation requirements in terms of balancing monetary yields and monetary debts as the outcome of market interaction. Hence, all the value-theoretic ordering structures depicting the agents' (intra- and intertemporal) interdependencies on the macro-level or meso-level are totally absent in such an approach. ${ }^{25}$ This approach is based on simply assuming a fullfledged elementary monetary system (unit of account, moneying procedure and rules for balancing yields and debts). Explaining how it came into existence and its link to exploitation, accumulation, reproduction and allocation is then no longer a subject matter of value theory. ${ }^{26}$

To recapitulate, the separation of interdependent agents requires that their interaction operates through a precarious articulation and realization of their product's social 'weight' in terms of a uniform unit of account, i.e. money. For the wage labourer, such a social weight can only be articulated and realized if there are entities for which the labourer's promise to work can establish the access to money, i.e. capitalist firms. Paradoxically, these firms can use the limits of the money relations (within the process of production) for improving their own abilities to monetize the products of their activities. This necessitates a calculation scheme in which the monetary requirements for the inputs are balanced against the monetary yields through selling the product. Hence, the essence of capitalism can be identified as thingified interaction with class distinction being the background for an accounting schema which determines individual activities.

\footnotetext{
${ }^{24}$ Not to be confused with 'monetarism' as a way to integrate money in neoclassical macroeconomics.

25 Accordingly, class differentiation is only derived from the different access to money.

${ }^{26}$ For the sake of completeness, it should be mentioned that by getting rid of the Ricardian elements of Marx's conception (labour theory of exchange value, constancy of embodied labour and distributive equilibrium), there is no 'transformation problem' as it was hypostatized in the post mortem discussion of manuscripts edited by Engels as the third volume of 'Das Kapital'. According to the view suggested in the present elaboration, different levels of value explanation have to be combined not simply by conserving them but by taking into account their modification and adaptation in the course of the decreasing abstraction. In this context, devaluation and revaluation are important parts of the explanation. It seems inappropriate to ignore the different levels of abstraction as a necessary element in the explanation procedure and to jump into more concrete forms of economic allocation without first accounting for their genesis in conceptual terms. Furthermore, in the capitalist mode of production material inputs and outputs of the production process are only exceptionally the same (hence, prices, quantities and qualities differ in a time-dependent manner as a rule). In accordance with the precarious interaction process being the background for the term of value, on the level of branches, there is no possibility either to identify constant technologies or to assume an equilibrium in physical and in distributional terms respectively (not to mention linearity assumptions).
} 


\section{Marxian modules for explaining economic dynamics and evolution}

\subsection{Value components and exploitation ${ }^{27}$}

Generally, the differentiation between the value components of capital ('constant capital', $c$; 'variable capital', $v$; and 'surplus value', $s v$ ) reflect a calculation device on the level of firms representing (i) the 'thingified' way of social interaction (they all are forms of value) and (ii) the purpose of entrepreneurial activities. This calculation device is primarily relevant for individual firms; furthermore, it structures the economic aggregates (where individual differences are not visible anymore) and correspondingly the dynamics of the economic society as a whole. In a certain way, the $(c, v, s v)$ calculation is a social convention depicting the specific historic form of the economic survival interest of the firm. ${ }^{28}$

According to the interpretation suggested here, this value differentiation is not necessarily linked to the labour theory of value as a common explanatory background as proposed by Marx. Rather, the value components are parts of long-term average prices reflecting the conditions of production, accumulation requirements, market relations and exit/entry possibilities in different branches and departments of production. Nevertheless, in conformity with Marx's perspective, these value components play an essential role for the rationale of capitalist production given the following basic conditions.

A first basic condition (already mentioned) for capitalist production is the existence of the specific social class of wage labourers who have access neither to goods and/or products which can be used as means of production nor to the money necessary to buy the latter (sc iii). In that context, labourers are not simple commodities: (i) they sell the ability to perform work, implying an acceptance to subordinate themselves under the organizing devices enforced by their capitalist appliers; (ii) nevertheless, they are paid in monetary terms (wages) like a normal commodity, and finally, (iii) their contract usually necessitates a consideration of their biological and cultural reproduction by taking into account individual options for spending their money wage as well as social coercion (regulation). Because the bearers of wage labour are human beings and due to the tensions inherent in the quasi-commodity of wage labour, wage labourers can and will associate in organizations for articulating their economic as well as political reproduction interests (cf. MEGA II/6, pp. 582).

A second basic condition for capitalist production is the necessary incompleteness of the price system in that resources and services which are not commodities (and which correspondingly are not produced by commodities) can be used in capitalist production (sc iv). These non-commodity resources and services can be applied by a capitalist firm to organize synergies between all elements of production in such a way that the sum total of costs for such a performance is less than the overall earnings which can be extracted from the market by selling the products resulting from it. Against this

\footnotetext{
${ }^{27}$ cf. MEGA II/6, pp. 183-197; MEGA II/3.1; MEGA II/3.6, pp. 1895-2117; MEGA II/4.1, pp. 5-135.

${ }^{28}$ Hence, there is no 'transmission' ('Übertragung') of the cost or value elements in production into a value part of the commodity as Marx seems to suppose sometimes (cf. MEGA II/6, pp. 211). Rather, the background for ascribing value components to commodities is an accounting convention partially reflecting the different shape and role of the production elements. Nevertheless, this accounting convention is the background for structuring reproduction and accumulation (cf. Aglietta 2015, pp. 53; Bryer 2017).
} 
background, labour is of central importance for realizing these synergies: it is the main instance for coordinating the various elements of production (cf. MEGA II/6, pp. 192). ${ }^{29}$ Although on the balance sheet labour costs are only depicted as one of numerous cost elements, these costs represent a unique ability of human beings. As 'variable capital', it is addressed as the main surplus producing agency in production. ${ }^{30}$

This ambiguous nature of wage labour as a simple cost element on the one hand and as a source of surplus value on the other hand gives the further commodity elements of production a complementary importance: they are not only another element of cost representing the material and non-material equipment for the labour activity. Moreover, as 'constant capital', they are socially conditioned as instruments of social subordination guaranteeing the surplus generating performance of labour. Hence, 'variable capital', 'constant capital' and 'surplus value' are complementary value forms of capitalist production.

These value-theoretic categories are crucial for explaining what is going on in capitalist firms. In this basic view, the main purpose of the firm is to generate surplus value. ${ }^{31}$ Hence, technological and organizational configurations as well as their changes are seen as being driven by the value structure: the use value elements of constant capital (like buildings, raw materials and machinery) and the labour performance are organized in such a way that the surplus value is positive and increasing over time. ${ }^{32}$ According to this central role of labour performance for generating surplus value, different modes of production can be distinguished: (i) prolonging the working time as much as possible (extensification of labour), (ii) increasing the amount of work in a given time period (intensification of labour), (iii) differentiating and specializing work components and delegating it to different groups (fragmentation of labour) and finally and most importantly (iv) increasing the singular labour productivity, i.e. reducing the amount of labour per unit of given output of a given firm (diminution of labour). ${ }^{33}$ Each of these modes of production implies a specific relation of constant and variable capital (what Marx called 'organic composition' if accidental price changes are excluded) being a result of increasing amounts of the respective use value elements as well as their devaluations. The general applicability of these modes of production as well as their possible combination is mainly determined by the availability of wage labourers. ${ }^{34}$ Against this background, exploitation occurs if the difference between the yields

\footnotetext{
${ }^{29}$ Due to his labour value bias, Marx pays no particular attention to the role of this uniqueness of labour for the generation of surplus value.

${ }^{30}$ To investigate if there are other elements in the production process which can be used as an unpaid synergy creator (cf. Roemer 1981, 52) is beyond the scope of this elaboration.

${ }^{31}$ This generation of surplus value 'by means of production' cannot be understood as a linear process (consisting simply of adding up ingredients) or as a simple input/output relationship (cf. Georgescu-Roegen 1971, pp. 211; Shaikh 2016, pp. 135 vs. pp. 212). Labour is not a good-like entity added to the inputs of production but a non-additive process delivered by the labourer which is an input as well as an output (though in different quality).

${ }^{32}$ There is no maximisation rule because the whole state space for combining raw materials, machinery and labour is not known to the capitalist. Rather, the latter has to explore this state space as regards its implications for surplus value.

${ }^{33}$ Strictly speaking, this presupposes that the quality of the product as well as of the labour remains the same in this comparison.

${ }^{34}$ On the level of individual capital, technological as well as organizational feasibility has to be taken into account as additional restrictions for immediately implementing the modes of production.
} 
generated by labour and the costs of applying labour is positive and can be privately appropriated by the capitalist (i.e. the private owner of the means of production). ${ }^{35}$

To recapitulate, the conditions enabling such a specific social circumstance are (i) a separation of social classes in terms of accessibility to means of production and money expressing itself in contractual asymmetries (incompleteness and coercion to contract), (ii) an incompleteness of the priced production ingredients and (iii) a social authority that is able to organize a hierarchical combination of production elements in such a way that synergies can be mobilized by applying labour. ${ }^{36}$

\subsection{Population dynamics, capitalist mode of production and power of wage labourers $^{37}$}

On the one hand, wage labourers are not produced by means of commodities; rather, their supply is governed by natural and cultural conditions like population growth, education and work attitude. However these conditions might be- they constitute an external limiting factor for capitalist production as a whole. On the other hand, capital and its value structure have an inherent tendency to grow due to capital's interest to augment its social 'weight' and to outperform competitors. This tendency is realized by increasing the surplus value by means of the modes of production mentioned above (cf. Section 3.1) and transforming (a part of) the surplus value realized in the market into additional elements of productive capital. Buying and applying these elements are the core of capital accumulation. Hence, there is no guarantee that wage labourers will be available in an amount required for pursuing accumulation. Rather, the growth of the value aggregates depends on the intertwined dynamics of surplus value and the available population of wage labourers.

The source for additional employment is determined firstly by the overall effect of the (old) modes of production activated for surplus production which might imply a diminution of labour required for a given amount of commodities. Secondly, the accumulated share of the surplus value has to be taken into account, and finally, the new mode of production influences the proportion of constant to variable capital of the accumulated surplus value. By relating these factors for additional employment to a given rate of growth in the labour population, three basic cases can be distinguished: an accumulation path with employment requirements below the growth of the labour

\footnotetext{
$\overline{35}$ This is not bound to a particular determination of the costs of applying labour (e.g. any kind of subsistence wage in terms of a bundle of goods which is a necessary assumption in the 'physicalist' approach; cf. Roemer 1981, pp. 54).

${ }^{36}$ Hence, in the given context, 'exploitation' has a specific analytical meaning combining class separation and capabilities of hierarchical organization of production activities under the condition of limited commodification. Only by abstracting from the social shaping of the production process and its specific way to use and mobilize unpriced elements, can exploitation be 'generalized'. This occurs firstly, by delinking it from labour as a special 'numéraire' (Roemer 1981, 204; 1982, pp. 283) and secondly, by linking it to any inequality in terms of property rights and exchange, this being only problematic from an ethical point of view (Roemer 1981, 205, 207; 1982, pp. 6, pp. 288; Elster 1985, pp. 166). This abstraction and generalization are the consequence of explaining the surplus over the commodity ingredients by magical (i.e. metaphysical(!)) features attached to 'technical' input/output coefficients resulting from the postulation of abstract mathematical properties (like 'productivity' of a matrix) for them (cf. e.g. Roemer 1981, 52). Surplus generation then results from a technical 'productivity' for which no reasonable explanation is given (cf. von Neumann's speculation about a similarity to thermodynamic potentials; von Neumann 1945/6, 2).

37 cf. MEGA II/7, pp. 487-630; MEGA II/6, pp. 523-643; MEGA II/4.1, pp. 385-432.
} 
population, a path more or less in accordance with the available labour population, and a path that is blocked by an insufficient labour population. Against this background, Marx tries to show in his accumulation theory proper (cf. MEGA II/6, pp. 561) that the growth impetus of capitalism is necessarily limited by population constraints and that there is a strong incentive to (temporarily) circumvent this constraint by selecting modes of production with a lower share of variable capital, i.e. by practicing the 'capitalist mode of production' with a tendency to increase the organic composition of capital. ${ }^{38}$ Hence, for a certain time span, the latitude of capitalist accumulation can be increased even if the labour population is a fixed given. Phases of economic development that are strongly limited by the labour population can then be distinguished from phases where this limit is becoming weak.

From these factors, a general selection bias in favour of the capitalist mode of production can be derived. According to Marx, its foundation is the interest of capital to exploit a given amount of labourers as much as possible on the one hand and to let capital grow as much as possible on the other hand. This interest is realized firstly by using machinery more productively (or by applying new machinery) so that a given amount of labour converts more raw material. In terms of production costs, this is tantamount to a relative increase of costs for nonlabour elements per unit of output and for the capital as a whole. ${ }^{39}$ This form of a labour-saving increased singular productivity is usually accompanied secondly by an increase of labour intensity (e.g. by transforming a social interest of the capitalists into an organizational and technical requirement) and, thirdly, by a fragmentation of labourers (e.g. by employing a decreasing proportion of skilled labourers and an increasing proportion of unskilled labourers) - both with the overall effect of reducing the relative size of variable capital.

This 'capitalist mode of production' is reinforced by the non-commodity features of labour. The hiring and firing as well as the social pressure included in the capitalist accumulation give the wage labourers the opportunity to transform their social experience into coordinated action and organizations like trade unions. This ability to cope with a changing relation of employed to total labour population in an organized and coordinated fashion determines the fluctuating power of wage labour. It is of essential importance not only for the workers in terms of the money wage itself but also for the capitalists in terms of the ambition to increase the organic composition of the accumulated capital (cf. MEGA II/6, pp. 573). ${ }^{40}$

\footnotetext{
${ }^{38}$ Problems of technological feasibility as well as the difficulties to realize an extra-profit, as they might appear on the level of individual capital, are ignored here.

39 This implies that the devaluation of raw material and machinery accompanying the increase of a single productivity is overcompensated by the social interest to increase the share of non-labour elements. This is triggered by (expected) constraints in terms of available labour population and/or (expected) problems for social subordination.

${ }^{40}$ The Marxian treatment of the capitalist mode of production is not free of ambiguities partly because Marx was impressed by a specific historical phase of technological change (mainly based on introducing machines as a substitute for labourers; cf. e.g. MEGA II/7, pp. 379) and partly because the conceptual arguments in favour of this mode of production are only implicitly formulated. Hence, critics had an easy time and mostly used this opportunity (again) to impose their own favourite model construction in the light of which Marx, of course, 'is wrong'. cf. e.g. Okishio (1961) and Elster (1983, pp. 158; 1985, pp. 119) for implementing a Sraffabased linear production approach being conceptually inappropriate for grasping the specificities of (capitalist) production (cf. Kliman 1996 for a critical assessment).
} 


\subsection{Reproduction requirements and value adaptation $\mathrm{I}^{41}$}

As a class relation in its manifestation through production and accumulation, capital is mediated by processes of verifying its social weight in market operations. This involves transforming produced commodities into money and transforming the latter into commodities necessary for continuing the production process. Hence, there is an overarching process in which the value of advanced capital passes through the different forms belonging to production as well as to the market. This is what Marx calls the circulation or the 'circuit' of capital. ${ }^{42}$ Therefore, a given amount of capital has to be allocated in terms of forms and in terms of time: it is not only continuously divided into money capital, commodity capital and production capital but also temporally frozen in these forms according to the requirements of production and market. The continuity of this circulation of capital is on the one hand dictated by the need to increase its value as a common denominator of the different forms the capital is taking in its circuit. On the other hand, this continuity is enforced by those elements of capital in production not physically disappearing during the production of commodities (like machinery, buildings and infrastructure). The costs of these elements are continuously calculated as a part of the costs of commodities produced by using them until these 'durable' elements of production are substituted by new ones. ${ }^{43}$ These elements are called 'fixed capital' unlike the elements of 'circulating capital' which physically disappear during commodity production and therefore are calculated on a one-time basis.

The reproduction of capital takes place in the circulation which constitutes a processing through the different forms of value. From the perspective of a single unit of the capital as a whole, this reproduction requires (i) that the capital is successively passing through all the forms of its circuit and (ii) that in every time step, the capital exists simultaneously in all forms of its circuit (cf. MEGA II/4.1, 179). ${ }^{44}$ Taking the properties of fixed capital as well as inventory requirements and necessary holding of

\footnotetext{
${ }^{41}$ cf. MEGA II/3.5, pp. 1701-1760; MEGA II/3.6, pp. 2214-2280; MEGA II/4.1, pp. 137-381; MEGA II/ 4.3 , pp. 32-56, pp. 285-363; MEGA II/11, pp. 1-522, 556-697, pp. 525-551, pp. 697-828.

42 Taken literally, the capital performs rather in an upward or downward spiral given the ever changing conditions in production and on the market.

43 This pragmatic reference to accounting conventions is different (i) from the Marxian (obscure) vision of value transfer ('Wertübertragung') and (ii) from the analytic calculation device suggested by von Neumann $(1945 / 6)$.

${ }^{44}$ Denoting CI, P, CO and M as input commodities, production elements, output commodities and money as the forms of capital in its circuit and depicting time as the row of a matrix, succession is tantamount to $\left(\begin{array}{ccccc}\mathrm{CI}_{0} & 0 & 0 & 0 & 0 \\ 0 & \mathrm{P}_{1} & 0 & 0 & 0 \\ 0 & 0 & \mathrm{CO}_{2} & 0 & 0 \\ 0 & 0 & 0 & \mathrm{M}_{3} & 0 \\ 0 & 0 & 0 & 0 & \mathrm{CI}_{4}\end{array}\right)$, simultaneity is tantamount to $\left(\mathrm{CI}_{0} \mathrm{P}_{0} \mathrm{CO}_{0} \mathrm{M}_{0} \mathrm{CI}_{0}\right)$ and succession and simultaneity is tantamount to $\left(\begin{array}{cccccccc}\mathrm{Cl}_{0} & \mathrm{P}_{0} & \mathrm{CO}_{0} & \mathrm{M}_{0} & 0 & 0 & 0 & 0 \\ 0 & \mathrm{P}_{1} & \mathrm{CO}_{1} & \mathrm{M}_{1} & \mathrm{CI}_{1} & 0 & 0 & 0 \\ 0 & 0 & \mathrm{CO}_{2} & \mathrm{M}_{2} & \mathrm{CI}_{2} & \mathrm{P}_{2} & 0 & 0 \\ 0 & 0 & 0 & \mathrm{M}_{3} & \mathrm{CI}_{3} & \mathrm{P}_{3} & \mathrm{CO}_{3} & 0 \\ 0 & 0 & 0 & 0 & \mathrm{CI}_{4} & \mathrm{P}_{4} & \mathrm{CO}_{4} & \mathrm{M}_{4}\end{array}\right)$ (the lower index indicating the steps in
} the circulation process). 
cash into account, this processing of capital is only possible if stocks and flows of all forms of value fit to each other (cf. MEGA II/4.1, pp. 194).

From the perspective of the capital as a whole, this has to be accomplished by demonstrating how the single units of capital interact in such a way that the reproduction for the capital as a whole is possible. Because Marx has already shown in his module about production and exploitation that a productive change of commodities into other commodities with enhanced value is possible (given the appropriate input commodities as well as wage labourers), and because for him, in the production itself, no interaction with other capitals is necessary, the problem of the circulation of the capital as a whole is simplified to the problem of transforming the commodities as an output of the production process into the commodities and wage labourers that are required as an input for successive production process.

For solving this problem, Marx refers on the one hand to the structure of capitalist value accounting (constant capital, variable capital and surplus capital) as a calculation device also for the produced commodities as a whole. On the other hand, he is taking into account a minimum of differentiation of commodities beyond their calculation in value terms in making the 'functional' distinction between commodities used as means of production and commodities used as means of consumption (distinction between 'departments' of commodity production). Furthermore, Marx is attempting to show the critical role of money in this reproduction for the capital as a whole by marking its difference to a simple 'metamorphosis of commodities'. ${ }^{45}$ Based on such a framing of the problem at stake, two simplifications are made in its solution: Firstly, it is assumed that the transformation of output commodities into input requirements is taking place in parallel, i.e. at the same time for all individual capital units (hence ignoring the asynchronous nature of its 'circuits'). Secondly, it is not systematically considered in which respect this process is shaped by the features of capitalist production and accumulation, especially the rising organic composition of capital and the fluctuating power of wage labourers. ${ }^{46}$

Referring to the 'grammar' of the capitalist accounting structure for each of the departments of the capital as a whole and given the abovementioned simplifications, the solution for the problem of reproducing the capital as a whole suggested by Marx is a double process: (i) the transformation of each department's output commodities into the input requirements of the successive production process (functionalist transformation) and (ii) a balancing of the value components

\footnotetext{
${ }^{45}$ In that sense, the Marxian explanation of the circulation of the capital as a whole is a deeper analysis of the abstract form of circulation in terms of ' $\mathrm{C}-\mathrm{M}-\mathrm{C}$ ' (cf. MEGA II/6, pp. 165). Nevertheless, the explicit focus on the capital a whole necessitates answering the question where money is coming from (and going to) and if it is initially allocated in such a way that the reproduction is feasible (cf. MEGA II/6, pp728, pp. 881; for a more general analysis Beckenbach 1987; Krause 1979). This must not be confused with the problem of proportionality between value aggregates.

${ }^{46}$ Nevertheless, various references to these features of the production process can be found in the manuscripts devoted to the 'circulation of capital' (cf. MEGA II/11, 495, 569, 646, 680, 742, pp743, 793, 795, 803, 814, 816). Unifying the perspective of reproduction and accumulation is also the background for Marx's assessment of Ricardo's accumulation theory (cf. MEGA II/3.3, pp. 1093-1165). Apart from that, the value theoretic reproduction analysis remains essentially different to an aggregated supply and demand analysis (as e.g. by Keynes (1974/1936)) — contrary to what Aglietta $(2015,154)$ maintains.
} 
involved in this transformation in such a way that they correspond to each other (value equilibration). ${ }^{47}$ Both requirements are threatened by the fact that capitalist accounting in value terms is not an ex ante planning device but rather an ex post result of aggregated market operations that are separated by the necessary use of money. Hence, it might happen that the reproduction of capital is disturbed by holding (hoarding) of money (or more generally by a 'viscous' circulation) as well as by inappropriate proportions between value aggregates in different departments. In the context of the modular reconstruction of the Marxian value theory suggested here, it is especially necessary to overcome the second abovementioned simplification, ${ }^{48}$ which is mostly due to the self-clarifying nature of the manuscripts devoted to the circulation of capital ${ }^{49}$ (contrary to the impression suggested by Engels' editing of this material) (cf. Introduction to MEGA II/11, pp. 843). If the production and accumulation of capital are dominated by the 'capitalist mode of production', a systematic divergence between the drivers on the level of the individual units (as well as on the level of departments) of capital on the one hand and the requirements for the reproduction of the capital as a whole on the other hand will occur. While all components in which the whole capital is divided (e.g. the departments of commodity production) are characterized by the same drive to value accumulation, a general application of the capitalist mode of production is tantamount to a slower growth of the aggregated value of the means of consumption compared with the growth of the aggregated value of the means of production. Hence, instead of value equilibration (and correspondingly a postulated path

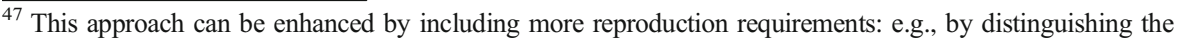
means of production department further into the components producing the elements of fixed capital vs. circulating capital or by distinguishing the means of consumption sector in luxury goods and normal consumption goods. Correspondingly, the conditions for transformation as well as for equilibrating then become more complicated. These broad functionalist enhancements are to be distinguished from the attempt to include all single technologies (and their input and output requirements) in such an aggregated reproduction scheme. An unsurmountable lack of knowledge prevents that such an approach can be assessed as reasonable. 48 'Die realen Bedingungen der Reproduktion, d.h. der kontinuierlichen Produktion, erscheinen theils erst innerhalb der Cirkulation, theils können sie erst nach der Analyse des Zirkulationsprozesses behandelt werden' (MEGA II/5, 456). This could be read in such a way that a chapter integrating the insights of volume I of 'Das Kapital' concerning the methods of surplus production and the phases of accumulation on the one hand and the reproduction requirements in circulation on the other hand is missing. Usually, this is ignored when the 'misuse' of the reproduction schemata is criticized (cf. e.g. Fine 2012, pp. 114).

49 cf. the analysis of Marx's numerical examples in manuscript viii on the circulation process (cf. MEGA II/11, pp. 806) by Morishima 1973, pp. 117; Reuten 1998, pp. 204; Benetti et al. 2013, pp. 85; Gehrke 2018. Overlooking their role for self-clarification has led many authors to false generalizations (such as generally postulating an adaptive role of accumulation in the consumption commodity department) in favour of a 'balanced growth' orientation (cf. e.g. Klein 1968, 160, 166; Morishima, ibid.; Desai 1979, pp. 147; Olsen 2015; Passarella 2016). Morishima (ibid., pp. 122) has also suggested correcting this false generalization by proposing a system of difference equations combining the equilibrium postulate with the same accumulation rules for both departments. In this system, the structural terms (e.g. the organic composition of capital) are given but can be differently parameterized. Furthermore, due to the missing link to surplus generation, the growth rates for the departments are determined externally. Nevertheless, even under these idealized conditions, it can be shown that a balanced growth is the exception and not the rule (ibid. 125) indicating that this idea of von Neumann is totally alien to Marx's concept of economic reproduction.
} 
of balanced growth), a value adaption has to be systematically taken into account as a part of the reproduction explanation. ${ }^{50}$ The features of this adaption process are firstly that the aggregated value components to be 'exchanged' between departments normally diverge and are violently changed to a level between the longer and the shorter side of this 'exchange'. 51 Secondly, the circulation process is slowing down increasingly (the more the value aggregates diverge) and thirdly, a part of the surplus value is fixed in additional inventories and additional cash holdings necessary for tackling such a situation. ${ }^{52}$

Finally, the general limits of the Marxian elementary analysis of the circulation and reproduction of capital should be emphasized (cf. Fine 2012, pp. 115). Marx has the general idea of a reproduction by means of commodity production. This closed system approach is backed by his hypothesis of capitalism as a generalized commodity production (cf. MEGA II/6, 69, MEGA II/4.1, 38; Beckenbach 2018). Hence, the critical role of elements which are not completely subsumable under such a hypothesis is underestimated or even neglected. In the context of reproduction analysis, these elements are wage labour and money. ${ }^{53}$

\footnotetext{
${ }^{50}$ Implications of surplus value analysis and the 'capitalist mode of production' for reproduction analysis are often emphasized in the literature related to reproduction (e.g. Aglietta 2015, pp. 57, pp. 206, pp284). Contrary to these attempts to accomplish the reproduction analysis in value terms, attempts have been made to derive from them a physical reproduction scaffold in terms of input as well as output quantities, technical coefficients and labour (cf. Morishima 1973, pp. 105; Benetti et al. 2013, pp. 68). Under very restrictive assumptions (like homogeneous use values in both departments, single techniques with constant returns to scale, adaptive saving rate in department II, uniform rate of exploitation - all alien to Marx's concept), it can be shown that a system of linear 'technologies' can be put 'behind' the value analysis enabling the analysis of reproduction requirements in technical categories '... which are independent from the social relations' (ibid. 75, 82). On the other hand, it has been suggested to accomplish the Marxian schemes by taking prices and market disequilibria into account (cf. e.g. Tsuru 1968, pp. 190; Erdös 1971, pp. 202; Koshimura 1975, pp. 95, pp. 128). If this is not being taken as an ad hoc enhancement, the figuring out of a ruling market value as well as a fluctuating market price on a more disaggregated level (cf. MEGA II/4.2, pp. 248 and Beckenbach 2015) has to be integrated. No such study exists yet.

${ }^{51}$ How the included devaluation and revaluation are allocated between the departments depends on specificities of the market conditions which are beyond the aggregated perspective of this article.

${ }^{52}$ Even if this adaptation, as an integral part of capital circulation, affects the reproduction as a whole, it is in itself not an explanation for the 'crisis' as the most precarious phase of the economic cycle. Such an explanation requires a synthesis of all conceptual modules Marx has suggested (cf. part II, Section 4 for a first attempt in this direction). In that sense, this adaptation approach to the circulation of the capital as a whole is essentially different from endeavours to derive (or deny) an explanation for economic crisis directly from the reproduction schemata (cf. Luxemburg 1969, pp. 79; Bauer 1913; Grossmann 1967, pp. 78; Sternberg 1969, pp. 84 and for an assessment Howard/King 1989, pp. 106, pp. 316), as well as from confining oneself to the supposed methodological role of these schemata (cf. Rosdolsky 1968, pp. 86, pp. 374, pp. 524) and finally from subsuming them under the mainstream concept of 'balanced growth' (cf. e.g. Bronfenbrenner 1973; Harris 1978, pp. 262; Desai 1979, pp147, pp. 161; Laibman 1981; Olsen 2015 and introduction above).

${ }^{53}$ In Section 4.2 a rudimentary attempt will be made to take these limits of commodity reproduction into account. A broader attempt for enhancing (and partly abandoning) the Marxian framework is given by the regulation approach (cf. Mavroudeas 2012, pp. 304 for a critical overview). The notion of 'regime' stemming from this approach will be used in part II, sections $2-4$ for characterizing parameter constellations.
} 
For Marx, the reproduction of wage labour is a result (i) of consuming the necessary means of consumption ${ }^{54}$ and (ii) of controlling the labour supply via the specific capitalist mode of production (MEGA II/4.1, 125f). But neither (i) nor (ii) is sufficient for reproduction: wage labour (as an ability) cannot be produced by commodities alone. As an ability, it is coupled to a socio-biological organism (which is fed but not determined by the consumption commodities); as a 'willingness' to comply, it is coupled to social subordination procedures (which are fostered but not fully determined by the overall thingification). Hence, complementary to the commodity production, it seems necessary to take a broader cultural background into account-not only as regards services for basic education, vocational training and household activities but also as orientation for the mode of consumption itself. Furthermore, the labour contract is not about a completely defined set of operations (cf. Simon 1951); rather, it tends to be determined by an asymmetric power relation. If this is realized in terms of the capitalist mode of production, it brings about the threat of ignoring biological reproduction requirements for the labourers and consequently of labour extinction. ${ }^{55}$ Both specificities of wage labour imply that a common interest is involved in the reproduction of wage labour. This manifests itself in institutional regulations as regards the length of the working day, the health conditions at the work place, as well as safeguarding against unemployment, illness and starvation. ${ }^{56}$

The same caveat applies for money. Even on an elementary level of analysis abstracting from credit and finance, money is not conceivable as a (specific) commodity alone. On the one hand, money is an essential element of capital's reproduction in that not only a general agreement about the unit of account is required but also the amount of money necessary for the continuity of the circuit and for the circulation of commodities has to be available. On the other hand, both these features transcend the simple commodity nature of money, requiring in addition an institutional character that necessitates some kind of regulation (e.g. fixing the basic unit of account, transforming private products into money units and managing the quantity of money). ${ }^{57}$

\footnotetext{
54 'In der That muß der Arbeiter sein Arbeitsvermögen durch Lebensmittel erhalten, aber diese seine Privatkonsumtion, die zugleich Reproduktion seines Arbeitsvermögens ist, fällt außerhalb des Productionsprozesses der Waare......Es ist der Arbeiter selbst, der das Geld in beliebige Gebrauchswerthe umsetzt, mit ihm beliebige Waaren kauft, und als Geldbesitzer, als Käufer von Waaren steht er ganz in demselben Verhältniß zu den Verkäufern von Waaren wie alle andren Käufer. Die Bedingungen seiner Existenz zwingen ihn natülich - ganz wie der Werthumfang des von ihm erworbnen Geldes - es in einem ziemlich umschriebnen Kreis von Lebensmitteln aufzulösen. Indeß ist hier einige Variation möglich.....er ist sich selbst verantwortlich für die Art, worin he spends his wages. Er lernt sich selbst beherrschen im Gegensatz, zum Sklaven, der eines Meisters bedarf' (MEGA II/4.1, 103, cf. ibid., 78).

$55 \mathrm{cf}$. the Marxian analysis of the problem of determining the length of the working day (cf. MEGA II/6, pp. 260).

${ }^{56}$ Cf. Aglietta 2015, pp. 151; Aglietta/Brender 1984 for an attempt to complete the Marxian concept of reproduction.

${ }^{57}$ In the manuscripts devoted to the elementary analysis of capitalist circulation, the monetary requirements are not systematically dealt with. The necessity of money as a unit of account, a medium of circulation and an instrument of hoarding for the circuit of capital is elaborated without answering the question how privately interested capitalist commodity producers can bring about and manage the monetary system. Rather, the main emphasis is laid on seeing the latter as an 'unproductive' circulation cost to be reduced by the advanced forms of credit and finance (cf. MEGA II/4.2, pp. 501). For an attempt to close this gap by using modern heterodox macroeconomic approaches, cf. Trigg (2006).
} 


\subsection{Competitive convergence of profit rates and value adaptation ${ }^{158}$}

The capital in its circuit provides the background for defining and measuring its performance in terms of the profit rate. In every circuit, the starting point of an initial amount of value is related to the final result in identifying the increment of value. This expresses the purpose of the whole process in that the 'social weight' of private activity should be increased. For such a relation between initial value and its increment, neither the difference between value components (constant vs. variable capital) nor the specificity of the different phases of the circuit (production vs. circulation) is of any importance. This alienated ('veräußerlichte') value relation is the profit rate.

In Section 2.2, it has been explained that the form of value depicts an elementary economic rivalry between the members of society. In the circulation (or the market), this rivalry necessarily proceeds in a sequence of buying and selling operations in which these members try to get an advantage over their rivals. On different levels (individuals, branches, departments), these competitive processes generate a performance outcome to which the competitors react by generating a new outcome. Hence, from the value perspective, competition is a hierarchical and recursive process with interdependent orientation marks on different levels. ${ }^{59}$

For Marx, the profit rate is capital's main benchmark in these competitive processes. On the one hand, economic rivalry seeks to get and protect an advantage in terms of the profit rate. On the other hand, rivalry erodes these advantages and reduces the corresponding differentials in terms of the profit rate either by imitating procedures that generate the original advantage or by counteracting them with an even more profitable procedure. The relative importance of these tendencies as well as the ordering between the different levels of economic activity determines the regime of competition. ${ }^{60}$ In that sense, neither on the level of individual capitals nor on the more aggregated level of branches and departments is an equalization of the profit rates a necessary outcome of competition if the value perspective as suggested here is taken as a background. ${ }^{61}$

Even if the concept of 'free competition' of the classical economists is adopted (which Marx does in some way ${ }^{62}$ ), capital's calculation with an average rate of profit (on the level of branches) is bound to specific exit and entry conditions, the handling of which requires some circulation costs and setup $\operatorname{costs}^{63}$ (or in modern terms: transaction

\footnotetext{
58 cf. MEGA II/4.2, pp. 212-284.

${ }^{59}$ Marx's main idea is that the interaction of individual capitals is ruled by dominating sub-groups representing a weighted average of the whole population of capitalists within a branch. The profit rates for different branches resulting from that are prone to competition between branches which itself can influence the competition within a branch. For a systematization of this rather complicated process, cf. Beckenbach (2015).

${ }^{60}$ Marx distinguishes a regime of competition based on average pricing from a regime based on marginal prices due to natural or social monopoly situations (cf. MEGA II/4.2, pp. 878). In the modern literature on capitalism, the notion of a regime has been broadened to include the dominant type of production, the class relations and the method of political regulation (cf. Aglietta 2015).

${ }^{61}$ Especially in the manuscript devoted to the overarching perspective of capital ('Gesamtprozess des Kapitals'), Marx is heavily influenced by Ricardo: he postulates an equilibration of the rates of surplus value and the rates of profit on the level of branches as an essential element of capitalism (cf. introduction above). 62 cf. MEGA II/4.2, 270 and Shaikh (2016, pp. 259) for a modern reformulation. Shaikh perpetuates the Ricardian bias in postulating a 'gravity' for the equalization of profit rates and simply assumes that forces towards profit rate convergence are stronger (or at least as strong) as forces towards their divergence (ibid., 118, 260, pp. 264).

${ }^{63}$ Especially important in the case of increasing returns to scale in production.
} 
costs) as well as a specific attitude towards risk or uncertainty. Depending on these barriers and their change over time, there might be differences in the profit rates on the branch level. This is even more the case if exit and entry processes are either blocked by monopoly situations on the branch level or substituted by capital investment diversified over different branches in such a way that profit rate differences are averaged out on the level of firms but not of branches (cf. Aglietta 2015, pp. 273). ${ }^{64}$

Hence, it has to be taken into account that the competitive pressure to equalize the rates of profits on disaggregated levels depends on the regime of competition. If such an equalizing pressure is given, this is tantamount to a value adaptation in the corresponding branches indicating a shifting in the 'social weight' of their outcome: a devaluation takes place in the branch with more favourable conditions for the profit rate and conversely a revaluation occurs in the branch with less favourable profit rate conditions. This shifting process between different branches is not necessarily symmetrical (with a zero overall effect) but rather depends on the branches' relative position. This is in sharp contrast to the idea of a value transfer (conserving the total amount of value) which Marx - according to his planning perspective-suggests in this case (cf. MEGA II/4.3, pp. 230). Instant and symmetrical adaptation and no adaptation at all as regards the profit rates can be seen as the extremes for various regimes if competition is included.

\subsection{Falling tendency of social profit rate ${ }^{65}$}

Before analysing specialized types of capital (like financial capital and agricultural capital) and their way to participate in the profit distribution, Marx focusses on the long-run prospect of the profit rate as the overarching performance indicator for capital, summarizing the value effects of all activities in production and circulation. In that context, he is considering the social profit rate as the profit rate on the national level averaged over all branches independently from the degree to which the profit rates are already equalized on the branch level due to competitive pressure. His hypothesis is that the social rate of profit has a tendency to fall. The reason for that is seen in the dominant role of the capitalist mode of production. According to this view, the rising organic composition of capital is tantamount to a decreasing relative importance of labour and of its performance as regards value creation. Neither the cheapening of the single elements of constant capital (due to single productivity increase) nor the increase of labour exploitation (due to limiting wage increases or to the extensification, intensification and fragmentation of labour performance) is considered to be sufficient for compensating this tendency in the long run.

The limited plausibility of this reasoning can be derived from two circumstances: firstly, that the manuscript in which it is presented has been written before the capitalist mode of production has been explained fully in the first volume of 'Das Kapital' and before the in-depth analysis of the process of circulation and reproduction has been figured out. Hence, Marx's reasoning is rather sketchy as regards the declining

\footnotetext{
${ }^{64}$ For a principal criticism of the equal-rate-of-profit assumption, cf. Farjoun/Machover (1983, pp16, pp. 24) and Farjoun (1984, pp. 12). This criticism is not bound to the probabilistic approach the authors suggest for Marxist Political Economy.

${ }^{65}$ cf. MEGA II/3.3, pp. 1063; MEGA II/3.5, pp. 1632-1651, pp. 1677-1682; MEGA II/4.2, pp. 285-340.
} 
tendency of the social rate of profit and is not a full blown representation of all features of production and circulation necessary for deriving this tendency. Secondly, it has to be noted that there is no attempt to take dynamic interdependencies of all the relevant variables into account, although to assume a 'tendency' requires considering a longer time span. Starting from the profit rate formula $r=\frac{s v}{c+v}$, to assess its tendency would require taking $r(\mathrm{t})=\frac{s v(\mathrm{t})}{c(\mathrm{t})+v(\mathrm{t})}$ for $t>t_{0}$ into account. Now, from the analysis of capitalist production (and the central role of the capitalist mode of production therein), it is obvious that the change of $s v$ is (at least partly) linked to the change of $c$ and $v$. This link is determined by the different modes of labour exploitation not yet fully specified, as mentioned above. ${ }^{66}$

For Marx, this tendency of the rate of profit to fall is a 'law' showing the transience of the capitalist form of production and circulation in its own terms. ${ }^{67}$ The reason for the law-like nature of this tendency in Marx's view is that it is in no way an intentional product of the protagonists' activities but rather an unintentional side effect of accumulation and competition (cf. MEGA II/4.2, pp. 337). But taking into account all features of capitalist production and circulation that Marx emphasized in the later manuscripts, this is simply an assertion. The conditions under which it actually applies need to be specified.

\section{Synthesis by way of a simulation model}

\subsection{General features of the simulation model}

Value is at the same time a common denominator of forms that capital per se takes in its 'circuit' and the measuring rod for its success in terms of realized value augmentation. As can be concluded from the review of the Marxian modules in Section 3 above, there are (at least) four obstacles to overcome: acquiring labour population, generating surplus by using labour in the appropriate way, implementing accumulation, enabling reproduction and overcoming tensions in terms of allocation. Instead of analysing explicitly how these

\footnotetext{
${ }^{66}$ Even if these different modes of labour exploitation are specified, the problem remains how the modes of exploitation are applied by individual capitalists: the available labour power is a '....Hauptbedingung der Produktion, eine bereits producirte Productivkraft, die in verschiednen, extensiven und intensiven Graden, angewandt und vernutzt werden kann....Länge und Intensivität des Arbeitstages gegeben, mag die Beschäftigung more or less full, in der That mehr oder weniger Tage in der Woche gearbeitet werden u.s.w. je nach Marktverhältnissen' (MEGA II/4.1, 350). Given the research on 'paradigms' (Dosi 1982), 'dominant designs' (Suarez/Utterback 1995) and 'regimes' (Aglietta 2015), it may be speculated that under these conditions, a certain synchronization between individual capitals in terms of applied exploitation modes takes place.

${ }^{67}$ Again, the weakness of Marx's reasoning (mainly due to its preliminary and sketchy character) is the background for numerous contributions to this topic in which a comprehensive reconstruction of his arguments is still missing (perhaps with the exception of Stamatis 1977). Not surprisingly, most of the modern contributions (for an overview of the issues: Mohun 2012, pp. 297) impose model constructions that do not depict the Marxian value concept adequately (e.g. Shaikh 1978, Laibman 2012, pp. 55) or even not at all (e.g. Okishio 1961, van Parijs 1980). But (legitimately) criticising these attempts (e.g. Kliman 1996, pp. 206) and figuring out the appropriate framework for the Marxian project of a long-run economic analysis beyond the linear input-output approach are two different things.
} 
processes operate on each stage of the circuit (commodity output, money, commodity input, production and augmented commodity output) in the model to be presented here, these processes will be summarized as transition elements for the initial value, especially for the components of the value building the 'grammar' of the capitalist calculation schema, i.e. for an initially given constant capital, variable capital and surplus value, the explanation of which can be derived from the different Marxian modules.

Hence, at the core of the simulation model is the dynamic for each of the value components being differently affected by the transition processes mentioned above. Due to the arbitrariness of the absolute magnitudes for the value components, a special emphasis will be placed on the proportions of these magnitudes as in $\frac{c}{v}, \frac{\mathrm{sv}}{\mathrm{v}}, \frac{\mathrm{sv}}{c+v}$ or $\frac{c_{1}+v_{1}+\mathrm{sv}_{1}}{c_{2}+v_{2}+\mathrm{sv}_{2}}$. It will be shown that these relations (and not the absolute magnitudes) are of central importance for the dynamics of the value structure.

In the model, essential features of the capitalist process will be depicted as endogenously determined variables. The scope of this model is limited firstly by its aggregation level, secondly by its focus on the core processes and thirdly by ignoring the influence of historical contingencies. These limitations are circumvented by introducing parameters influencing the interdependencies of the variables. These parameters can be varied according to the explanatory focus. Apart from that, this variation shows the robustness of the results as regards these 'external' influences.

\subsection{Mathematical and algorithmic structure}

The general idea behind the following mathematical model is that the value dynamics can be depicted in terms of (dynamic) equations. According to the perspective sketched in the previous section, the value dynamics are decomposed into interdependent equations for $c, v$ and $\mathrm{sv}$. Hence, it is assumed that the transformation rules for the value components remain unchanged over time. ${ }^{68}$ But this persistent core does not exclude that the dynamics might switch between structural change and balanced growth as well as that the outcomes might change dramatically for different parameter constellations (which might be explained by referring to historical constellations). Ruptures as they occur in the real history of capitalism cannot be approached in such a manner, although their conditions might be clarified by such a modelling approach. ${ }^{69}$

The dynamics of surplus value is depicted as it happens for the Marxian standard case of the 'capitalist mode of production' (cmp: increasing productivity with diminishing relative labour requirements due to rising organic composition of capital) (cf. Section 3.2 above). Based on determining sv by the product of the rate of surplus value (rsv) and the labour population (LP), this condition for $\mathrm{cmp}$ is taken into account by the inverse influence of the power of wage labourers $\left(\frac{1-w}{w}\right)$ on rsv. Accordingly, the dynamics of the surplus value is depicted in the following equation $(\gamma$ being a scaling parameter indicating the overall strength of the combination of all methods for increasing the surplus value mentioned in Section 3.1 and $i$ the index for the economic entities under consideration):

\footnotetext{
${ }^{68}$ In principle, it is possible to relax this assumption by introducing a change of transformation rules depending on the state of the variables. Then, second-order transformation rules are assumed as given. Such an enhancement is beyond the scope of this elaboration.

${ }^{69} \mathrm{Cf}$. Aglietta 2015, 19. Aglietta is suggesting a conceptual approach 'below' equation modelling and 'above' particular historical narratives.
} 


$$
\Delta m_{i}(t)=\gamma \frac{1-w(t)}{w(t)} \operatorname{rsv}_{i}(t) \operatorname{LP}_{i}(t) ; \gamma \leqslant 1
$$

Corresponding to the focus on cmp, the dynamics of the constant and the variable capital are also shaped by the power of wage labourers $(w)$ : the higher $w$, the higher the incentive to increase the share of additional constant capital (adc) (and to decrease the share of additional variable capital, adv ${ }^{70}$ :

$$
\begin{gathered}
\operatorname{adc}_{i}(\mathrm{t})=\mathrm{w}(t)\left(\mathrm{sv}_{i}(t)+\Delta \mathrm{sv}_{i}(t)\right) \\
\operatorname{adv}_{i}(t)=(1-w(t))\left(\operatorname{sv}_{i}(t)+\Delta \mathrm{sv}_{i}(t)\right) .
\end{gathered}
$$

While this appropriately depicts the constellation Marx had in mind, for also taking into account other constellations, the influence of $w$ on the accumulation is parameterized more generally according to:

$$
\begin{gathered}
\operatorname{adc}_{i}(t)=(\beta w(t)+(1-\beta) w(\mathrm{t}))\left(\mathrm{sv}_{i}(t)+\Delta \mathrm{sv}_{i}(t)\right), \\
\operatorname{adv}_{i}(t)=((1-\beta) w(t)+\beta w(t))\left(\operatorname{sv}_{i}(t)+\Delta \mathrm{sv}_{i}(t)\right) ; \beta \leqslant 1 .
\end{gathered}
$$

The constant capital and the variable capital in the next time step are influenced not only by the newly accumulated elements but also by the devaluation effects resulting from the diffusion of new technical and/or organizational configurations. ${ }^{71}$

In the case of variable capital, this devaluation is tantamount to the increase of surplus value $\left(\Delta \mathrm{sv}_{i}\right)$, indicating an increase of exploitation. ${ }^{72}$ In the case of constant capital, this devaluation is weighted by the organic composition $\left(\Delta \mathrm{sv}_{i} \frac{c_{i}+\operatorname{adc}_{i}}{v_{i}+\operatorname{adv}_{i}}\right)$ in such a way that the proportional effect is the same for constant and variable capital. Hence, the overall change for constant and variable capital amounts to:

$$
\Delta c_{i}(t)=\operatorname{adc}_{i}(t)-\Delta \operatorname{sv}_{i}(t) \frac{c_{i}(t)+\operatorname{adc}_{i}(t)}{v_{i}(t)+\operatorname{adv}_{i}(t)}
$$

\footnotetext{
${ }^{70}$ For the sake of simplicity, it is assumed that the surplus value is only used for accumulation.

71 The additional requirements for technical as well as organizational preparation, commodity storage and money holdings for realizing accumulation are ignored here (cf. Lowe 1976, pp10, pp. 109, pp. 176 and p 272 for the importance of these elements).

${ }^{72}$ For the sake of simplicity, it is assumed here that the share of $v$ and $m$ changes in an inverse proportional manner. While this is explicitly true for the increase of productivity of labour, the change of its intensity or of its fragmentation may bring about a non-proportional inverse change.
} 


$$
\Delta v_{i}(t)=\operatorname{adv}_{i}(t)-\Delta \mathrm{sv}_{i}(t)
$$

It is assumed that there is a constant and exogenously given rate of growth for the population $(\delta)$ :

$$
P(t+1)=P(t)+\delta P(t) ; \delta<1 \text {. }
$$

That part of the population which is engaged in production is called the labour population (LP). The dynamics of the value structure of the applied capital as well as the dynamics of the labour population are influenced by the (bargaining) power of the wage labourers $(w)$. The higher this power of the wage labourers, the higher their wage and the more the increase of surplus value as well as the increase of variable capital is damped down (cf. Eqs. (1) and (3)). ${ }^{73}$ This variable is mainly determined by the relationship between the size of the labour population (LP) and the population as a whole (P) ( $\alpha$ being a parameter for varying the weight of this variable, e.g. for different degrees of worker trade union organization):

$$
w(t)=\left(\frac{\operatorname{LP}(t)}{P(t)}\right)^{\alpha} ; 0<\alpha \leqslant 1 .
$$

Hence, the power of wage labour increases relative to the rate of employment and the degree to which the influence of the unemployed can be controlled, i.e. the lower $\alpha$ (cf. Fig. 1).

The dynamics of the labour population in each industrial department is influenced by the growth of the variable capital $\left(\frac{\Delta v_{i}}{v_{i}}\right)$ and the amount of labourers already employed $\left(\mathrm{LP}_{i}\right)$. As a first restriction, it has to be taken into account that for each department, the required additional labourers are indeed available, i.e. that new and already employed labourers in one department are below or equal to the difference between total population and the already employed workers in the other department $\left(\mathrm{P}-\mathrm{LP}_{i, j}\right.$ for the $j, i$ department). A second restriction for capital's access to new workers is given by the 'strategic' interest of always having a buffer of available workers ('industrial reserve army' according to Marx). It is assumed that the strategic interest in having such a buffer increases, the higher the value of $w$ and the larger the labour population. If these restrictions do not pertain, the reproduction in value terms - and the labour population accordingly - remain unchanged (simple reproduction). ${ }^{74}$ Hence, the dynamics of the labour population can be formalized in the following equation ( $\rho$ being a parameter for the strength of the political interest in having a reserve army of wage labourers):

\footnotetext{
${ }_{73}$ Because this model is restricted to the value structure, the determination of wages is not explicitly dealt with. Nevertheless, it can be calculated either as nominal per capita wage (cw) by dividing the sum of the variable capital by the number of labourers, $\mathrm{cw}(t)=\frac{v(t)}{\mathrm{LP}(t)}$, or by including the inverse effect of $w$ on labour performance, $\operatorname{pcw}(t)=\frac{v(t)}{\frac{I}{w(t)} \mathrm{L}(t)}$.

74 This is similar to the Marxian conceptualization of different phases of accumulation in volume 1 of 'Das Kapital' (cf. MEGA II/6, pp. 561)
} 


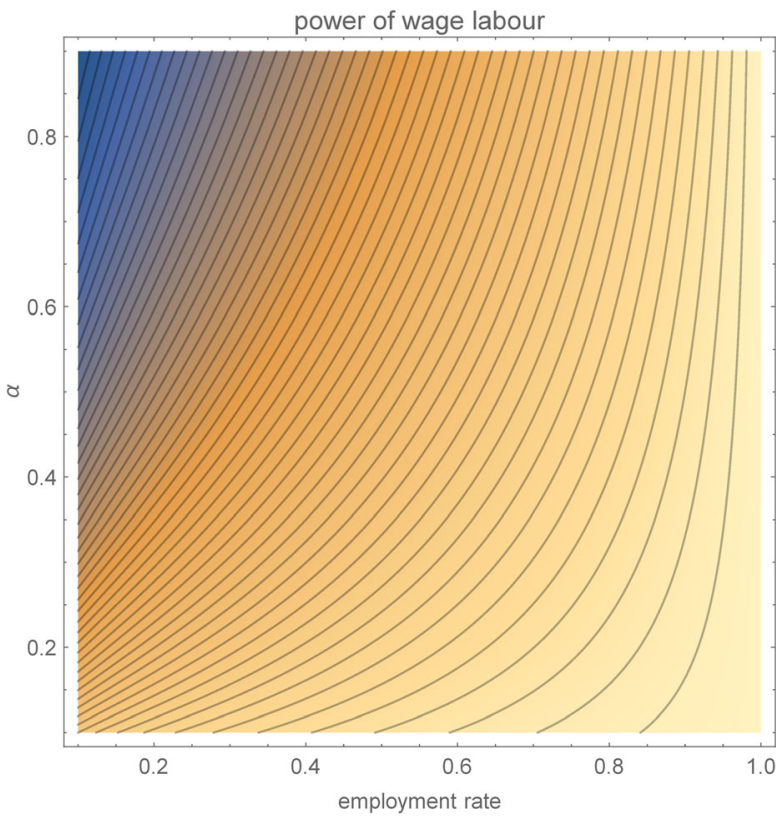

Fig. 1 Contour diagram of the determinants for the power of wage labour. The brighter colour indicates higher wage labour power

$$
\mathrm{LP}_{i}(t+1)=\left\{\begin{array}{l}
\mathrm{LP}_{i}(t)+\frac{\Delta v_{i}(t)}{v_{i}(t)} \mathrm{LP}_{i}(t), \quad \text { if } \mathrm{LP}_{i}(t)+\frac{\Delta v_{i}(t)}{v_{i}(t)} \mathrm{LP}_{i} \leqslant P(t)-\mathrm{LP}_{j}(t)-\rho w(t) \operatorname{Lp}(t) ; 0 \leqslant \rho \leqslant 1 \\
\mathrm{LP}_{i}(t) \text { else }
\end{array}\right.
$$

The dynamics of the value reproduction is determined by the internal conditions for every value component (cf. Eqs. (1)-(7) above) provided that the population conditions (cf. Eq. (10)) are met. On the level of the capital as a whole, the reproduction requires an equal amount of value which is delivered from a given department to the other departments and of the value received by this department from other departments. This requirement on the level of the whole capital is not necessarily in accordance with the internal dynamics given for each department (cf. Section 3.3 above). Hence, there is a need for value adaptation so that values delivered and values received are equalized for each department. This adaptation is modelled in such a way that the value components to be exchanged between departments are added up in terms of their respective endogenously determined amount, divided by the number of departments involved and normalized in each department accordingly. ${ }^{75}$ In the simple case of a twodepartment economy $(i=1,2)$ with no consumption of capitalists, this means that the new variable capital in department $1\left(v_{1}+\Delta v_{1}\right)$ and the new constant capital in department $2\left(c_{2}+\Delta c_{2}\right)$ are adapted according to

\footnotetext{
${ }^{75}$ In the general case of $n$ different departments for a given department $i$ the sum of values delivered to $j$, other departments (out $\mathrm{t}_{i j}$ ) has to be equal to the sum of values received from other departments $\left(\mathrm{in}_{i j}\right)$. Hence, $\sum_{i=1}^{n}$ out $_{i j}, \forall i=\sum_{j=1}^{m} \mathrm{in}_{i j}, \forall j$. 


$$
c_{2}(t)+\Delta c_{2}(t)+\operatorname{adaptc}_{2}(t)=v_{1}(t)+\Delta v_{1}(t)+\operatorname{adaptv}_{1}(\mathrm{t})
$$

Depending on the market conditions, a multitude of adaptation regimes between the extremes of either $\operatorname{adaptc}_{2}(t)=0$ or $\operatorname{adaptv}_{1}(t)=0$ are possible if $v_{1}+\Delta v_{1} \neq c_{2}+\Delta c_{2}$. Without any further specification of these market conditions (which is beyond the value perspective taken here), it is reasonable to assume the case of half distance adaptation:

$$
c_{2}(t+1)=c_{2}(t)+\Delta c_{2}(t)-\varphi\left(c_{2}(t)+\Delta c_{2}(t)-\left(v_{1}(t)+\Delta v_{1}(t)\right)\right)
$$

and

$$
v_{2}(t+1)=v_{1}(t)+\Delta v_{1}(t)+\varphi\left(c_{2}(t)+\Delta c_{2}(t)-\left(v_{1}(t)+\Delta v_{1}(t)\right)\right)
$$

which hold for $\varphi=0.5$ :

$$
c_{2}(t+1)=v_{1}(t+1)=0.5\left(c_{2}(t)+\Delta c_{2}(t)+v_{1}(t)+\Delta v_{1}(t)\right) .
$$

Accordingly, in case of a changing value structure, revaluation/devaluation $\left(\mathrm{ev}_{i}\right)$ in every department induced by reproduction requirements amounts to:

$$
\begin{aligned}
& \mathrm{ev}_{1}(\mathrm{t})=0.5\left(v_{1}(t)+\Delta v_{1}(t)-\left(c_{2}(t)+\Delta c_{2}(t)\right)\right) \\
& \mathrm{ev}_{2}(\mathrm{t})=0.5\left(c_{2}(t)+\Delta c_{2}(t)-\left(v_{1}(t)+\Delta v_{1}(t)\right)\right) .
\end{aligned}
$$

Compared with the value dynamics in each department, this implies a revaluation or devaluation in a different degree for every department if the size of the respective value components is different. Accordingly, using Eqs. (6) and (7), the amount of this disproportion (dp) can be depicted as:

$$
\operatorname{dp}(t)=\left|\left(c_{2}(t)+\operatorname{adc}_{2}(t)-\Delta \mathrm{sv}_{2}(t) \frac{c_{2}(t)+\operatorname{adc}_{2}(t)}{v_{2}(t)+\operatorname{adv}_{2}(t)}\right)-\left(v_{1}(t)+\operatorname{adv}_{1}(t)-\Delta \operatorname{sv}_{1}(t)\right)\right|
$$

It is assumed that this adaptation requirement has a twofold effect:

Firstly, in the industrial departments, there are additional circulation costs in terms of inventories and search activities. This circulation costs (commodity-related transaction costs, tcc) are weighed with the relative value magnitude of the industrial departments:

$$
\begin{gathered}
K_{i}(t)=c_{i}(t)+v_{i}(t)+\mathrm{sv}_{i}(t) ; i=1,2, \\
K(t)=K_{1}(t)+K_{2}(t),
\end{gathered}
$$

and parameterized for both of them as: 


$$
\operatorname{tcc}_{i}(t)=\lambda 3 \frac{K_{i}(t)}{K(t)} \mathrm{dp}(t) ; \lambda 3<1
$$

These circulations costs have to be subtracted from the surplus value in the corresponding department.

Secondly, the growth of capital is damped down by a factor $(\lambda 2<1)$ if the disproportion (cf. Eq. (17)) is beyond a parameterized threshold $(\lambda 1)$. Combining these adaptations with the population conditions (cf. Eq. (10)), using

$$
\mathrm{aP}_{i}(t)=\mathrm{LP}_{i}(t)+\frac{\Delta v_{i}(t)}{v_{i}(t)} \mathrm{LP}_{i}(t) \leqslant P(t)-\mathrm{LP}_{j}(t)-\rho w(t) \operatorname{Lp}(t) ; 0 \leqslant \rho \leqslant 1 ; i, j=1,2 ; i \neq j
$$

for abbreviating this population condition, and taking finally into account that the surplus value in each department is reduced by a part $(\varphi)$ of $K_{i}$ being used for acquiring money (money related transaction costs, tcm) (cf. Section 2.2), ${ }^{76}$ the value reproduction for the whole capital can be depicted as:

$$
\begin{aligned}
& c_{1}(t+1)= \begin{cases}\lambda 2\left(c_{1}(t)+\Delta c_{1}(t)\right), & \text { if } \mathrm{aP}_{1}(t) \\
c_{1}(t) \text { else }\end{cases} \\
& v_{1}(t+1)=\left\{\begin{array}{l}
\lambda 2 \frac{1}{2}\left(c_{2}(t)+\Delta c_{2}(t)+v_{1}(t)+\Delta v_{1}(t)\right), \text { if } \mathrm{aP}_{1}(t) \\
v_{1}(\mathrm{t}) \text { else }
\end{array}\right. \\
& c_{2}(t+1)=\left\{\begin{array}{l}
\lambda 2 \frac{1}{2}\left(c_{2}(t)+\Delta c_{2}(t)+v_{1}(t)+\Delta v_{1}(t)\right), \text { if } \mathrm{aP}_{2}(t), \\
c_{2}(\mathrm{t}) \text { else }
\end{array},\right. \\
& v_{2}(t+1)=\left\{\begin{array}{ll}
\lambda 2\left(v_{2}(t)+\Delta v_{2}(t)\right), & \text { if } \mathrm{aP}_{2}(t) \\
\mathrm{v}_{2}(\mathrm{t}) \text { else }
\end{array},\right. \\
& \mathrm{sv}_{i}(t+1)= \begin{cases}\lambda 2\left(\mathrm{sv}_{i}(\mathrm{t})+\Delta \mathrm{sv}_{i}(t)\right)-\mathrm{tcc}_{i}(t)-\phi K_{i}(t), & \text { if } \mathrm{aP}_{\mathrm{i}}(t) \\
\mathrm{sv}_{i}(\mathrm{t}) \text { else } & \end{cases}
\end{aligned}
$$

\footnotetext{
${ }^{76}$ Considering the capital as a whole, this corresponds to the necessary hoarding of money for transaction purposes and for advancing wages. The amount of these money hoardings depends on circumstances which can be specified only on a more disaggregated level, e.g. the reciprocity of payments and clearing opportunities. Nevertheless, on the level of basic monetary analysis, disaggregated or not, no credit is necessary for expanded economic reproduction.
} 
The departmental rates of profit in such a system of reproductive values can now easily be derived from the dynamics of the value components:

$$
\begin{aligned}
r_{i}(t+1) & =r_{i}(t)+\Delta r_{i}(t)=\frac{\mathrm{sv}_{i}(t)}{c_{i}(t)+v_{i}(t)}+\frac{\Delta \mathrm{sv}_{i}(t)}{\Delta c_{i}(t)+\Delta v_{i}(t)} \\
& =\frac{\mathrm{sv}_{i}(t)+\Delta \mathrm{sv}_{i}(t)}{c_{i}(t)+\Delta c_{i}(t)+v_{i}(t)+\Delta v_{i}(t)}
\end{aligned}
$$

It has been argued above (cf. Section 3.4) that it is not reasonable to start the valuetheoretic approach with the assumption of full competition including a distribution of profit between industrial departments in such a way that the departmental profit rates are equal. By the same token, it is not reasonable to ignore the pressure of exit and entry processes between departments with significantly different rates of profits (expressed in value terms). Rather, it seems appropriate to take into account the adaption of sectoral surplus values in such a way that there is a tendency towards equal profit rates in value terms. This tendency is influenced by the difference in terms of profit rate endogenously generated in every department on the one hand and of the degree of competition (or of exit/entry pressure) on the other hand. Taking the profit rate difference between the departments as a starting condition, equalization (eq $(t))$ amounts to:

$$
\begin{gathered}
\frac{\mathrm{sv}_{1}(t)+\mathrm{eq}(t)}{c_{1}(t)+v_{1}(t)}=\frac{\mathrm{sv}_{2}(t)-\mathrm{eq}(t)}{c_{2}(t)+v_{2}(t)} \text { and hence } \\
\mathrm{eq}(t)=\frac{\mathrm{sv}_{1}(t)\left(c_{2}(t)-v_{2}(t)\right)-\mathrm{sv}_{2}(t)\left(c_{1}(t)-v_{1}(t)\right)}{c_{1}(t)+c_{2}(t)+v_{1}(t)+v_{2}(t)} .
\end{gathered}
$$

Parameterizing the degree of competition as $\xi$, the surplus value dynamics is modified according to ${ }^{77}$

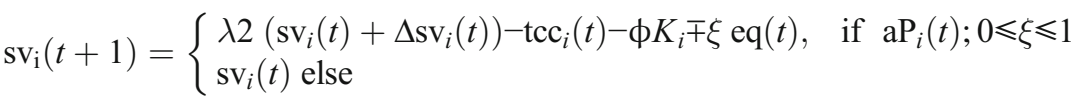

Given such a specification of the departmental profit rates, finally, the total rate of profit (cf. Section 3.5) amounts to:

$$
r(t+1)=\sum_{i=1}^{2} \frac{\mathrm{sv}_{i}(t)+\Delta \mathrm{sv}_{i}(t)}{c_{i}(t)+\Delta c_{i}(t)+v_{i}(t)+\Delta v_{i}(t)}
$$

\footnotetext{
${ }^{77}$ A specification of the nature of competition may include that $\xi$ is not the same in all departments so that the sum of the overall value adaptation diverges from zero. If $\xi=1$ in both departments, their proportion tends to grow linearly (according to the increase of organic composition).
} 


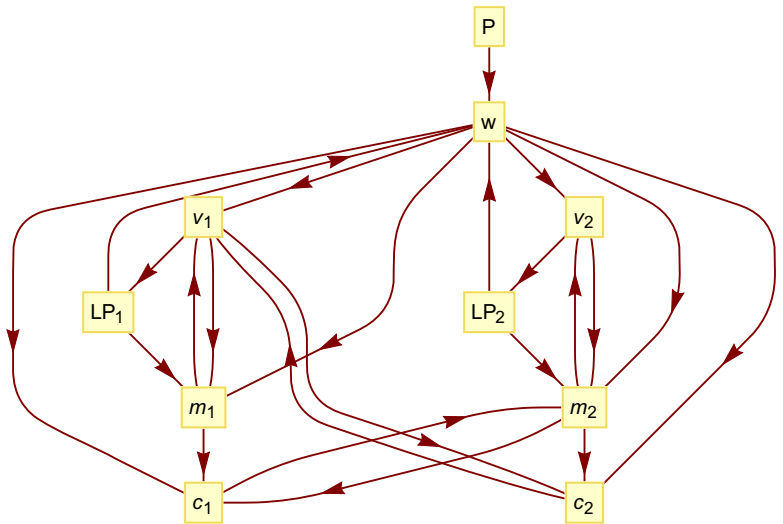

Fig. 2 Interdependencies of variables in the dynamic equation system

This model of the core dynamics of capitalism in value terms consists of first-order difference equations for $c_{1}, c_{2}, v_{1}, v_{2}, \mathrm{sv}_{1}, \mathrm{sv}_{2}, P, \mathrm{LP}_{1}, \mathrm{LP}_{2}$ and $w$. These equations have a large number of interdependencies and thus constitute a dynamic equation system (cf. Fig. 2) for which no analytical solution procedure exists. Hence, the working of this system will be explored in part II through numerical simulation. ${ }^{78}$

Funding Information Open Access funding provided by Projekt DEAL.

\section{Compliance with ethical standards}

Conflict of interest The author declares that he has no conflict of interest.

Open Access This article is licensed under a Creative Commons Attribution 4.0 International License, which permits use, sharing, adaptation, distribution and reproduction in any medium or format, as long as you give appropriate credit to the original author(s) and the source, provide a link to the Creative Commons licence, and indicate if changes were made. The images or other third party material in this article are included in the article's Creative Commons licence, unless indicated otherwise in a credit line to the material. If material is not included in the article's Creative Commons licence and your intended use is not permitted by statutory regulation or exceeds the permitted use, you will need to obtain permission directly from the copyright holder. To view a copy of this licence, visit http://creativecommons.org/licenses/by/4.0/.

\section{References}

\section{Marx}

MEGA II/1.1: Karl Marx, Ökonomische Manuskripte 1857/8, , Berlin: Dietz-Verlag 1976

MEGA II/1.2: Karl Marx, Ökonomische Manuskripte 1857/8, Berlin: Dietz-Verlag 1981

MEGA II/2: Karl Marx, Ökonomische Manuskripte und Schriften 1858-1861, Berlin: Dietz-Verlag 1980

MEGA II/3.1: Karl Marx, Zur Kritik der Politischen Ökonomie (Manuskript 1861-1863), Berlin: Dietz-Verlag 1976

\footnotetext{
78 'Computer simulation is a powerful method both for examining the logical consistency of a theoretical model and exploring its conclusions' (Okishio 1992, v). cf. Laibman 1987/8 for assessing the relevance of simulations for synthesizing Marx's ideas about accumulation and growth.
} 
MEGA II/3.2: Karl Marx, Zur Kritik der Politischen Ökonomie (Manuskript 1861-1863), Berlin: Dietz-Verlag 1977

MEGA II/3.3: Karl Marx, Zur Kritik der Politischen Ökonomie (Manuskript 1861-1863), Berlin: Dietz-Verlag 1978

MEGA II/3.4: Karl Marx, Zur Kritik der Politischen Ökonomie (Manuskript 1861-1863), Berlin: Dietz-Verlag 1979

MEGA II/3.5: Karl Marx, Zur Kritik der Politischen Ökonomie (Manuskript 1861-1863), Berlin: Dietz-Verlag 1980

MEGA II/3.6: Karl Marx, Zur Kritik der Politischen Ökonomie (Manuskript 1861-1863), Berlin: Dietz-Verlag 1982

MEGA II/4.1: Karl Marx, Ökonomische Manuskripte 1863-1867, Berlin: Dietz-Verlag 1988

MEGA II/4.2: Karl Marx, Ökonomische Manuskripte 1863-1867, Berlin: Dietz-Verlag 1992

MEGA II/4.3: Karl Marx, Ökonomische Manuskripte 1863-1867, Berlin: Akademie-Verlag 2012

MEGA II/6: Karl Marx, Das Kapital - Kritik der Politischen Ökonomie, Erster Band Hamburg 1872, Berlin: Dietz-Verlag 1987

MEGA II/7: Karl Marx, Le Capital, Paris 1872-1875, Berlin: Dietz-Verlag 1989

MEGA II/11: Karl Marx, Manuskripte zum Zweiten Buch des “Kapitals”, 1868 bis 1881, Berlin: AkademieVerlag 2008

MEGA II/14: Karl Marx/Friedrich Engels, Manuskripte und redaktionelle Texte zum Dritten Buch des "Kapitals", 1871 bis 1895, Berlin: Akademie-Verlag 2003

\section{Other}

Aglietta M and Orléan A (1984) La violence de la monnaie. Paris, Presses Universitaire de France

Aglietta M and Orléan A (2002) La monnaie entre violence et confiance. Paris, Odile Jacob

Aglietta M (2015) A theory of capitalist regulation: the U.S. experience. London, Verso

Aglietta M and Brender A (1984) Les Métamorphoses de la Société Salariale: La France en Projet. Paris, Calmann-Levy

Anderson JR (1993) Rules of the mind. Hillsdale/NJ, Lawrence Erlbaum Associates

Arrow KJ and Hahn FH (1971) General competitive analysis. Amsterdam, North-Holland

Bauer O (1913) "Die Akkumulation des Kapitals." Die Neue Zeit 31: 831-38, 862-874

Beckenbach F (1987) Zwischen Gleichgewicht und Krise: Zur Konstitution einer Geldökonomie. Frankfurt/ M, Haag+Herchen

Beckenbach F (2015) Artikel "Marktpreis". Historisch-Kritisches Wörterbuch des Marxismus. W. F. Haug, F. Haug, P. Jehle and W. Küttler (eds.). Hamburg, Argument-Verlag. 8/II: 1784-1793

Beckenbach, F. (2018). Warenreproduktion mittels Waren? Eine kritische Würdigung des ökonomietheoretischen Ansatzes von Marx. Auf der Suche nach dem Ökonomischen - Karl Marx zum 200. Geburtstag. R. Lucas, R. Pfriem and C. Thomasberger (eds.). Marburg, Metropolis-Verlag: 43-81

Beckenbach F (2019) Monism in modern science: the case of economics. Advancing pluralism in teaching economics-international perspectives on a textbook science. S. Decker et. al. (eds.) New York, Routledge

Benetti C and et al. (2013) Monetary objectivity and physical objectivity in Marx's reproduction model. New contributions to monetary analysis. F. Ülgen (ed.). New York, Routledge: 68-90

Benetti C, Bidard C, Klimovsky E, Rebeyrol A (2014) Disequilibrium, reproduction and money: a classical approach. Metroeconomica 65(3):524-540

Benetti C, Bidard C, Klimovsky É, Rebeyrol A (2015) Temporary disequilibrium and money in a classical approach. Cahiers D’Économie Politique 69:159-184

Benetti C and Cartelier J (1980) Marchands, Salariat et Capitalistes. Paris, Maspero

Bronfenbrenner M (1973) The Marxian macro-economic model: extensions from two departments. Kyklos 26(4):201-218

Cartelier J (2018) Money, markets and capital-the case for monetary analysis. London, Routledge

De Vroey M (1982) On the obsolenscence of the Marxian theory of value: a critical review. Capital \& Class $6(2): 35-59$

De Vroey M (1985) La Théorie Marxiste de la Valeur, Version Travail Abstrait. Un Échiquier Centenaire: La Théorie de la Valeur et Formation des Prix. G. Dostaler and Lagueux, M. (eds.), Paris, Éditions la Découverte: $31-57$

Debreu G (1959) Theory of value: an axiomatic analysis of economic equilibrium. New Haven, Yale University Press

Desai M (1979) Marxian economics. Oxford, Basil Blackwell 
Desai M (2004) Marx's revenge-the resurgence of capitalism and the death of statist socialism. London, Verso

Dosi G (1982) Technological paradigms and technological trajectories. Res Policy 11:147-162

Elster J (1983) Explaining technical change: a case study in the philosophy of science. Cambridge, Cambridge University Press

Elster J (1985) Making sense of Marx. Cambridge, Cambridge University Press

Erdös P (1971) Contributions to the theory of capitalist money, business fluctuations and crises. Budapest, Akadémiai Kiadó

Farjoun E and Machover M (1983) Laws of chaos: a probabilistic approach to political economy. London, Verso

Farjoun E (1984) The production of commodities by means of what? Racardo, Marx, Sraffa-the Langston memoral volume. E. Mandel and A. Freeman. London, Verso: 11-41

Fine B (2012) Economic reproduction and the circuit of capital. The Elgar companion to Marxist economics. B. Fine and A. Saad-Filho (eds.). Cheltenham, Edward Elgar: 111-117

Fourcade M (2009) Economists and societies-discipline and profession in the United States, Britain and France, 1890 s to 1990 s. Princeton, Princeton University Press

Gehrke C (2018) "Marx's reproduction schemes and multi-sectoral growth models." The European Journal of the History of Economic Thought 25(5): 859-892

Georgescu-Roegen N (1971) The entropy law and the economic process. Cambridge/Mass., Havard University Press

Grossmann, H. (1967). Das Akkumulations- und Zusammenbruchsgesetz des kapitalistischen Systems. Frankfurt/M, Verlag Neue Kritik

Harris DJ (1978) Capital accumulation and income distribution. London, Routledge \& Kegan Paul

Harvey D (2013) A companion to Marx's capital

Heinrich M (2011) Entstehungs- und Auflösungsgeschichte des Marxschen "Kapital”. Kapital \& Kritik - Nach der neuen Marx-Lektüre. W. Bonefeld and M. Heinrich (eds.). Hamburg, VSA: 155-193

Hodgson G (1997) Economics and evolution and the evolution of economics. Economics and Evolution. J. Reijnders. Cheltenham, Edward Elgar: 9-40

Howard MC and King JE (1989) A history of Marxian economics, volume I, 1883-1929. London, Macmillan Keynes JM (1974/1936) The general theory of employment, interest and money. London, Macmillan

Klein RL (1968) Theories of effective demand and employment. Marx and modern economics. D. Horowitz. New York,: 138-175

Kliman A (1996) A value-theoretic critique of the Okishio theorem. Marx and Non-Equilibrium Economics. A. Freeman and G. Carchedi. Aldershot, Edward Elgar: 206-224

Koshimura S (1975) Theory of capital reproduction and accumulation. Ontario, DPG Publishing

Krause U (1979) Geld und abstrakte Arbeit - Über die analytischen Grundlagen der Politischen Ökonomie. Frankfurt/M, Campus

Kurz HD (2018) Will the MEGA² edition be a watershed in interpreting Marx? The European Journal of the History of Economic Thought 25(5):1-25

Kurz HD, Salvadori N (2001) Sraffa and von Neumann. Review of Political Economy 13(2):161-180

Laibman D (1981) Two-sector growth with endogenous technical change: a Marxian simulation model. Q J Econ 96(1):47-75

Laibman D (1987/88) Growth, technical change, and cycles: simulation models in Marxist economic theory. Science \& Society 51(4):414-438

Laibman D (2012) Political economy after economics-scientific method and radical imagination. New York, Routledge

Leontief WW (1941) The structure of American economy: an empirical application of equilibrium analysis. Cambridge/Mass., Harvard University Press

Lopes TC, Neder HD (2017) Sraffa, Leontief, Lange: the political economy of input-output economics. EconomiA 18:192-211

Lowe A (1976) The path of economic growth. Cambridge, Cambridge University Press

Luxemburg R (1969) Die Akkumulation des Kapitals. Frankfurt/M, Verlag Neue Kritik

Marshall A (1972) Principles of economics: an introductory volume. London, Macmillan

Mavroudeas SD (2012) The regulation approach. The Elgar companion to Marxist economics. B. Fine and A. Saad-Filho (eds.). Cheltenham, Edward Elgar: 304-309

Mirowski P (1991) Postmodernism and the social theory of value. J Post Keynes Econ 13(4):565-582

Mohun S (2012) The rate of profit. The Elgar companion to Marxist economics. B. Fine and A. Saad-Filho (eds.). Cheltenham, Edward Elgar: 295-303

Morishima M (1973) Marx's economics: a dual theory of value and growth. Cambridge, Cambridge University Press 
Moseley F (2016) Money and totality-a macro-monetary interpretation of Marx's logic in capital and the end of the transformation problem. Chicago, Haymarket Books

Neumann Jv (1945/6) “A model of general economic equilibrium.” Review of Economic Studies 13(1): 1-9

Okishio N (1961) "Technical change and the rate of profit." Kobe University Economic Review, 7, 85-90

Okishio N, Ed. (1992). Business cycles. Frankfurt/M, Peter Lang

Olsen EK (2015) Unproductive activity and endogenous technical change in a Marxian model of economic reproduction and growth. Review of Radical Political Economics 47(1):34-55

Orléan A (2014) The empire of value-a new foundation for economics. Cambridge, MIT Press

Parys W (2016) The interaction between Leontief and Sraffa: no meeting, no citation, no attention? Eur J Hist Econ Thought 23(6):971-1000

Polanyi K (2001) The great transformation: the political and economic origins of our times. Boston, Beacon Press

Reuten G (1998) The status of Marx's reproduction schemes: conventional or dialectical logic? The circulation of capital-essays on volume two of Marx's capital. C. J. Arthur and G. Reuten. Basingstoke, MacMillan Press: $187-229$

Ricardo D (1975) On the principles of political economy and taxation. The works and correspondence of David Ricardo, vol. I, Cambridge, Cambridge University Press

Roemer JE (1981) Analytical foundations of Marxian economic theory. Cambridge, Cambridge University Press

Roemer JE (1982) A general theory of exploitation and class. Cambridge/Mass., Harvard University Press

Rosdolsky R (1968) Zur Entstehungsgeschichte des Marxschen 'Kapital'. Frankfurt/M, Europäische Verlagsanstalt

Shaikh A (1978) Political economy and capitalism. Camb J Econ 2:233-251

Shaikh A (1981) The poverty of algebra. The value controversy. I. Steedman and et. al. London, Verso: 266300

Shaikh A (2016) Capitalism: competition, conflict, crises. Oxford, Oxford University Press

Simon HA (1951) A formal theory of the employment relationship. Econometrica 19:293-305

Smith A (1784/1979) An inquiry into the nature and causes of the wealth of nations. Indianapolis, Liberty Classics

Sraffa P (1960) Production of commodities by means of commodities-prelude to a critique of economic theory. Cambridge, Cambridge University Press

Stamatis G (1977) Die 'spezifisch kapitalistischen' Produktionsmethoden und der tendenzielle Fall der Profitrate. Frankfurt/M, Verlag Mehrwert

Steedman I (1977) Marx after Sraffa. London, NLB

Sternberg, F. (1971). Der Imperialismus. Frankfurt/M, Verlag Neue Kritik

Suarez EF, Utterback JM (1995) Dominant designs and the survival of the firms. Strateg Manag J 16:415-430

Trigg AB (2006) Marxian reproduction schema. New York, Routledge

Tsuru S (1968) Keynes vs. Marx: The methodology of the aggregates. Marx and modern economics. D. Horowitz. New York: 176-202

Van Parijs P (1980) The falling-rate-of-profit theory of crisis: a rational reconstruction by way of obituary. Rev Radical Political Econ 12(1) 